\title{
LA CORONACIÓ DE FERRAN D'ANTEQUERA: L'ORGANITZACIÓ I ELS PREPARATIUS DE LA FESTA'
}

\author{
ROSER SALICRÚ I LLUCH \\ Institució Milà i Fontanals \\ (CSIC, Barcelona)
}

\begin{abstract}
SUMARI
1. La coronació de Ferran d'Antequera.- 2. Els precedents: les coronacions dels reis d'Aragó.- 3. Observació del ritual i de la tradició.- 4. La data: canvis i trasllats.- 5. El finançament: demandes per coronatge, novell regiment, novella cavalleria $i$ maridatge.- 6 . La generositat reial: dons $i$ regals.- 7. Els convidats.- 8. L'allotjament dels convidats.- 9. L'allotjament reial.- 10. Les robes: vestidures i paraments.- 11. Les joies.- 12. La cera: torxes i brandons.- 13. L'entrada a Saragossa.- 14. L'ofici de la cerimònia religiosa.- 15. El convit.- 16. Els entremesos.- 17. Els joglars.- 18. Les justes i torneigs.
\end{abstract}

\footnotetext{
*Aquest estudi fou elaborat el 1993, com a treball de doctorat de l'assignatura L'evolució del calendari festiu des de l'Alta a la Baixa Edat Mitjana, impartida, durant el curs acadèmic 1992-1993, pel Prof. Dr. Salvador Claramunt, dins el Programa de Doctorat Formes de vida de la Catalunya medieval del Departament d'Història Medieval, Paleografia i Diplomàtica de la Facultat de Geografia i Història de la Universitat de Barcelona (bienni 1991-1993).

Abreviatures utilitzades: $\mathrm{ACA}=$ Arxiu de la Corona d'Aragó; $\mathrm{C}$. = Cancelleria; CODOIN = Colección de Documentos Inéditos del Archivo de la Corona de Aragón; $\mathbf{C R}=$ Cartes Reials; fol., fols. = foli, folis; $M R=$ Mestre Racional; reg. = registre; $r$. = recto; $R P$ = Reial Patrimoni; v. = verso.
} 


\section{LA CORONACIÓ DE FERRAN D’ANTEQUERA}

Les relacions que cronistes i comentaristes fan de la coronació de Ferran d'Antequera superen, segurament, totes les notícies que tenim de coronacions anteriors ${ }^{1}$.

Per bé que a la Corona d'Aragó la transmissió del poder al monarca s'hagués institucionalitzat al marge de la coronació i que aquesta no fos, en conseqüència, l'acte que li conferia el poder sobre els diversos regnes de la Corona, hom considerava que augmentava la dignitat reial. Per això, els sobirans catalano-aragonesos instituïren, en motiu de llurs coronacions, l'organització d'un gran espectacle polític que posava de manifest, solemnement, davant dels seus súbdits i dels altres poders, el seu caràcter reial, i que, a la vegada, sacralitzava la seva persona ${ }^{2}$.

Tanmateix, és evident que la coronació de Ferran I ha de ser analitzada i interpretada amb unes coordenades del tot diferents: les particularitats de la forma d'accés al tron del primer Trastàmara que cenyí la corona catalano-aragonesa $\mathrm{i}$ les contingències polítiques que l'acompanyaren convertiren aquell espectacle polític -que, amb tota intencionalitat, seguí al peu de la lletra el ritual fixat pels seus predecessors ${ }^{3}$ - en una veritable cerimònia de propaganda i de legitimació.

Aquest fort component legitimador i les dimensions que el monarca va atribuir tant a l'acte com a les celebracions que l'acompanyaren expliquen aquesta gran profusió de notícies cronístiques ${ }^{4}$, encapçalades per la crònica

\footnotetext{
'Així ho considera E. SARASA SÁnCHEZ, Fernando I y Zaragoza (La Coronación de 1414), "Cuadernos de Zaragoza" 10 ([1977]), p. 6. Agraeixo a la Dra. M.I. Falcón que em donés a conèixer l'existència d'aquesta publicació i a B. Canellas que tingués l'amabilitat de facilitar-mela.

${ }^{2}$ B. Palacios Martín, La coronación de los reyes de Aragón. 1204-1410. Aportación al estudio de las estructuras políticas medievales, València, 1975, pp. 206-208.

${ }^{3}$ Ens referim, evidentment, a l'Ordinació de Pere el Cerimoniós. Vegeu el paràgraf corresponent a la nota i la nota 22 .

${ }^{4}$ Trobem descripcions de la coronació de Ferran d'Antequera, per exemple, a la Crónica del rey don Juan el Segundo de Pérez de Guzmán (Crónicas de los reyes de Castilla, vol. II, Madrid, "Biblioteca de Autores Españoles" 68, 1953, pp. 358-360); a P. TOMICH, Històrias e conquestas, capítol XLVII, pp. 128-129 de la reimpressió facsímil de l'edició de 1534 amb índexs de J. SÁEZ RICO (València, Anúbar, 1970) o pp. 265-267 de l'edició de "La Renaixensa" (Barcelona, 1886); a la Crónica incompleta del reinado de Fernando I de Aragón editada per L. Vela Gormedino, Saragossa, 1985, capítol XXVII, pp. 45-49; a J. de ZURITA, Anales, llibre XII, capítol XXXIV, pp. 384-388; a J. de BLANCAS, Coronaciones de los Serenísimos Reyes de Aragón, Saragossa, 1641, capítol IX, "De la Coronación del Rey Don Hernando el I llamado el Honesto", pp. 91-116, que també publica M. TinTó, Cartas del baile general de
} 
d'Álvar García de Santa María coronació i que, per tant, fou testimoni directe dels esdeveniments, constitueix la relació més completa, precisa i detallada de la coronació de Ferran I i és, de fet, la font essencial de la resta de cròniques ${ }^{6}$. I com que, a més, la coronació de Ferran d'Antequera fou la darrera de les coronacions litúrgiques dels reis d'Aragón, tal com testimonia Zurita ${ }^{8}$, això fa que encara esdevingui més destacable.

Valencia, Joan Mercader, al rey Fernando de Antequera, València, 1979, pp. 305-318, d'on donarem, a partir d'ara, la referència; $i$, sobretot, com assenyalem tot seguit, a la primera part de la crònica d'Álvar García de Santa María, la que abasta el període cronològic de 1406 a 1419 i que, tot i que no ho sigui, és coneguda tradicionalment com la part "inèdita".

${ }^{5}$ Per bé que, des de la publicació dels fragments inèdits de la seva crònica, el 1972 (D. FERRO, Le parti inedite della "Crónica de Juan II" di Álvar García de Santa María, Venècia, 1972; la posterior edició pòstuma de Carriazo [J. de M. CARRIAzo, Crónica de Juan II, Madrid, 19], rẹiteradament anunciada [cf., per exemple, idem, Notas para una edición de la "Crónica" de Alvar García, dins Estudios dedicados a Menéndez Pidal, vol. III, Madrid, 1952, pp. 489-505], no ens és, aquí, de cap utilitat, puix que es tracta d'una edició parcial que no arriba fins a 1414), aquesta ja es trobi completament publicada, la dispersió de fragments entre diverses obres dificulta la seva consulta i fa que, sovint, almenys pel que fa a la coronació de Ferran d'Antequera, no sigui tinguda en compte o que, fins i tot, sigui confosa i suplida per la Crónica de Pérez de Guzmán, a desgrat dels buits i deficiències d'aquesta al respecte. La part de la crònica de García de Santa María que fa referència a la coronació de Ferran d'Antequera es troba publicada en dos fragments. Per un costat, Blancas en transcriu fidelment, sense amagar-se'n (Coronaciones, p. 91, citat per M. TINTÓ, Cartas del baile, p. 305), una bona part, en especial la que recull els prolegòmens de la celebració i la relació dels assistents, però eludeix completament els actes de coronació de la reina Elionor (en honor de la qual hi hagué el principal torneig i les justes organitzades pel rei) i alguns dels fragments de les festes que més ens afecten, com ara la descripció dels espectacles $i$ entremesos que acompanyaren cadascun dels plats del banquet; per un altre costat, Donatella Ferro complementa les Coronaciones de Blancas editant la part de la crònica que narra els esdeveniments des de la vigília de la coronació fins a la fi de les festes (D. FERRO, Le parti inedite, pp. 97-134).

"Així ho demostra I. MACDONALD, A Coronation Service 1414, "Modern Language Review" (juliol 1941), pp. 351-368. Al llarg d'aquest article, l'autora remet repetidament a un altre estudi seu, Early Spanish Drama. Coronation Celebration in 1414, en vies de publicació al "Bulletin Hispanique" del mes de juny de 1940; tanmateix, aquest article no degué arribar a publicar-se ja que, entre 1940 (volum XLII) i 1943 (volum XLV), no hem sabut localitzar-lo en cap dels números d'aquesta revista.

${ }^{7}$ Els seus successors, Alfons el Magnànim i Joan II, es limitaren, a l'inici de llurs respectius regnats, amb certa solemnitat però sense la mateixa magnificència $i$ vistositat, a jurar els Furs d'Aragó a la catedral de Saragossa, en poder del justícia; $c f$. A. Durán GudIOL, El rito de la coronación del rey en Aragón, "Argensola. Revista de Ciencias Sociales del Instituto de Estudios Altoaragoneses" 103 (1989), p. 34.

8"Ordenóse la fiesta y aparato de la coronación con la mayor pompa y solemnidad que se vio jamás en estos reinos; y fue la postrera que ha habido hasta nuestros tiempos, porque los reyes sucesores no se coronaron con aquella majestad y triunfo que se ordenó en la coronación deste príncipe y como la usaron sus antecesores"; $c f$. J. de ZURITA, Anales de la Corona de Aragón, ed. preparada per A. CANELlAS LÓPEZ, vol. V, Saragossa, 1974, llibre XII, capítol XXXIV, p. 385 . 
La brevetat del regnat del monarca, unida a l'especial interès que ell mateix mostrà per exterioritzar la seva majestat a través de les festes de la coronació, fan que aquestes festes siguin ineludibles per qualsevol que intenti apropar-se a la seva figura o al seu regnat. Segurament per això la coronació de Ferran d'Antequera ha desvetllat diverses vegades l'interès dels investigadors que li han dedicat estudis.

Abans de redactar la que, pròpiament, s'ha de considerar l'única biografia existent sobre Ferran d'Antequera', Inez Macdonald ja havia fet una aproximació crítica a la relació que la Crónica del rey don Juan de Pérez de Guzmán feia dels actes de la coronació de Ferran I, tot comparantla amb l'Ordinació de Pere el Cerimoniós i amb un dels manuscrits de la crònica, aleshores inèdita, de García de Santa María, amb la finalitat de demostrar que aquella, almenys pel que fa a aquestes celebracions, censurava i manipulava les informacions aportades per Álvar García, la seva font principal $^{10}$.

Francesca Vendrell també dedicà unes planes a la presència de jueus a les festes de la coronació de Ferran $\mathrm{I}^{11}$ poc després d'haver analitzat, juntament amb Ángels Masià, la figura i la trajectòria de Jaume d'Urgell en un estudi on, lògicament, Ferran I té un paper destacat ${ }^{12}$.

Esteban Sarasa, en ocupar-se d'Aragó durant el regnat de Ferran I, tampoc no pogué evitar dedicar un capítol a la seva coronació a Saragossa ${ }^{13}$, a la que ja s'havia aproximat prèviament, sempre a partir de les cròniques ${ }^{14}$.

Finalment, Margarida Tintó, l'única que aporta documentació inèdita no cronística, també tractà alguns aspectes de la coronació de Ferran en la

${ }^{9}$ I. MaCDONALD, Don Fernando de Antequera, Oxford, 1948.

${ }^{10}$ I. MaCdonald, A Coronation Service.

"F. VENDRELL DE MiLlÀs, Presencia de la comunidad judia en las fiestas de la coronación de Fernando de Antequera en Zaragoza, "Sefarad" 17 (1957), pp. 380-385.

${ }^{12} \mathrm{~F}$. VENDRELl DE MILlàs, Á. MASIÀ DE ROS, Jaume el Dissortat, darrer comte d'Urgell, Barcelona, 1956.

${ }^{13}$ E. SARASA SÁnchez, Aragón en el reinado de Fernando I (1412-1416). Gobierno y Administración. Constitución Política. Hacienda Real, Saragossa, 1986, pp. 82-86.

${ }^{14}$ E. SARASA, Fernando I y Zaragoza. 
seva tesi doctoral ${ }^{15} \mathrm{i}$, posteriorment, es referí, puntualment, a la corona que el monarca utilitzà en aquella ocasió ${ }^{16}$.

Per bé que totes aquestes aproximacions hagin partit, quasi exclusivament, de les cròniques publicades, l'excepcionalitat de la coronació de Ferran d'Antequera també ha quedat palesa, a causa de la ingent massa documental que va generar i que, en un regnat tan curt, encara pren més relleu, en els fons de l'Arxiu de la Corona d'Aragó. La informació que aporten aquestes fonts arxivístiques, pràcticament inèdita, és paral lela i complementària de la informació cronística. Lògicament, reflecteix més els preparatius i l'entourage de les festes que no pas els actes en sí mateixos, però ens permet contrastar i relacionar perfectament, amb una precisió de vegades fins $i$ tot sorprenent, totes dues menes de notícies.

El nostre objectiu no és altre, doncs, que el d'aportar un contrapunt documental, bàsicament constituït per referències extretes dels registres de Cancelleria de l'Arxiu de la Corona d'Aragó, a les notícies cronístiques ja conegudes de la coronació de Ferran d'Antequera.

\section{ELS PRECEDENTS: LES CORONACIONS DELS REIS D'ARAGÓ}

La primera coronació reial d'Aragó que es coneix amb certesa és la de Pere el Catòlic, que va desplaçar-se personalment a Roma per ser coronat pel Papa, tot i que la seva visita a la Santa Seu tingué com a objectiu principal la renovació de la infeudació dels seus estats al primat. Pocs mesos després, el juny de 1205, Innocenci III va atorgar una butlla que permetia als reis i reines d'Aragó, prèvia sol-licitud al Pontífex cada cop que pertoqués, ser solemnement coronats a Saragossa per mediació del metropolità de Tarragona ${ }^{17}$.

Com que la conducta de Pere el Catòlic vinculà la coronació a la renovació del vassallatge a la Santa Seu, l'anàlisi de l'evolució posterior de

\footnotetext{
${ }^{15}$ M. Tintó, Cartas del baile, pp. 63-80 i documents 22,22 bis i 23 de l'Apèndix Documental. Com indica el títol del seu estudi, però, l'autora utilitza quasi exclusivament cartes reials, no pas registres de Cancelleria.

${ }^{16} \mathrm{M}$. Tintó SALA, A propòsit de la corona del rei Ferran d'Antequera, "Estudis Històrics i Documents dels Arxius de Protocols" VIII (1980), pp. 143-148.

${ }^{17} \mathrm{La}$ butlla es troba publicada a D. MANSILLA, La documentación pontificia hasta Inocencio III (965-1216), Roma, 1955, pp. 346-347.
} 
les coronacions d'Aragó esdevé indestriable del seguiment de l'esforç que la monarquia va haver de fer per eludir aquesta subjecció, ja que, durant la cerimònia, els gestos que simbolitzaven aquest vassallatge eren múltiples ${ }^{18}$.

Les grans línies del cerimonial de coronació dels reis d'Aragó, estructurat en quatre parts (unció, coronació, recepció de cavalleria i jurament mutu de reis i súbdits), quedaren dissenyades amb Alfons el Liberal. En endavant, els seus successors ja no van introduir-hi canvis, ans només van augmentar-ne la solemnitat ${ }^{19}$.

Tanmateix, la primera gran coronació d'Aragó fou la d'Alfons el Benigne que, a més de conservar el profund significat simbòlic de les dels seus antecessors, ja adquirí, precedida d'amplis preparatius, el caràcter de gran espectacle ${ }^{20}$. L'augment de solemnitat de la coronació d'aquest rei, descrita detalladament a la Crònica de Ramon Muntaner, va anar acompanyat de la introducció de nous cerimonials per guiar-la. Per aquest motiu, Bonifacio Palacios considera que de fet fou ell i no pas el seu fill qui va renovar el ritus de la coronació d'Aragó ${ }^{21}$, i que Pere el Cerimoniós es limità a seguir al peu de la lletra el cerimonial que havia fixat el seu pare i a posar-lo per escrit ${ }^{22}$.

La coronació d'Alfons el Benigne i els seus festeigs ja tingueren la mateixa estructura que les successives. La vigília de la coronació, una gran comitiva va acompanyar-lo des del palau de l'Aljafería de Saragossa fins a la Seu, on passà la nit en vetlla. L'endemà, després de la cerimònia de la

${ }^{18}$ B. Palacios, La coronación, p. 27.

${ }^{19}$ Ibidem, p. 115.

${ }^{20}$ Ibidem, pp. 201-204.

${ }^{21}$ Ibídem, pp. 209-210.

${ }^{22}$ Ordinació feta per lo molt alt e molt excel-lent príncep e senyor lo senyor en Pere Terc, rey d'Aragó, de la manera con los reys d'Aragó se faran consegrar e ells mateys se coronaran, "CODOIN", vol. V, pp. 267-303 (l'ordinació per a la coronació del rei, extreta de l'obra esmentada, també pot trobar-se a M. TinTó, Cartas del baile, pp. 280-298). De l'Ordinació del Cerimoniós se'n coneixen dues redaccions (cf. B. PALACIOS, La coronación, pp. 229-240 i 259269), la segona de les quals incorpora, també, la coronació de les reines (Ordinació feta per lo dit senyor rey de la manera con les reynes d'Aragó se faran consegrar e los reys d'Aragó les coronaran, "CODOIN", vol. V, pp. 304-316); fins aleshores, en coronar-se, els reis no havien estat casats ( $c f$. B. PALACIOS, La coronación, p. 259). Fins a Alfons el Benigne, el cerimonial havia seguit el Pontifical d'Osca que, inspirat en el Pontifical Romà, s'havia anat adaptant progressivament, tal com demostren les anotacions marginals que hi figuren, a les necessitats i voluntats de la corona catalano-aragonesa; A. DURÁN El rito de la coronación, pp. 34-89, publica la traducció de la litúrgia de la coronació d'aquest manuscrit, conservat a la Catedral d'Osca. 
coronacio i d'haver armat nous cavallers, el rei va tornar, també en comitiva, cap a l'Aljafería, per celebrar-hi el convit, durant el qual els nobles van adoptar oficis de servidors. Amb cada plat, d'un total de deu, hi hagué una dança, espectacles de joglars, versos i cançons. Les festes duraren una setmana, al llarg de la qual se celebraren diversos festeigs, torneigs, taules, jocs de canyes i escaramusses ${ }^{23}$.

Alfons el Benigne va suprimir tota aparença que pogués remetre a la recepció del regne de mans de l'Església: durant la seva coronació, per primera vegada, es col·locà, ell mateix, la corona; prengué directament de sobre l'altar el pom i el ceptre, els altres dos símbols del poder reial; i, de la mateixa manera, també agafà l'espasa per al seu armament de cavalleria. La seva investidura, divina, no li arribà, per tant, mediatitzada per cap intermediari humà ${ }^{24}$; però, de tota manera, després d'haver pres de l'altar la corona amb les seves pròpies mans i d'haver-se-la col-locada, va permetre que els tres infants presents (Joan, arquebisbe de Toledo i oficiant de la cerimònia, Pere i Ramon Berenguer) la hi retoquessin. Durant la coronació del Cerimoniós, el metropolità de Saragossa intentà tornar a aconseguir imposar la corona al monarca, però el rei Pere ni tan sols va consentir, a diferència del seu pare, que ell ni ningú altre la hi redrecés ${ }^{25}$.

\section{OBSERVACIÓ DEL RITUAL I DE LA TRADICIÓ}

En contra del que ens podria fer pensar la llarga tradició historiogràfica que li ha estat contrària (però, probablement, també per la particularitat de la seva forma d'accés al tron catalano-aragonès i per les incidències que, tant a priori com a posteriori, l'acompanyaren), Ferran I demostrà interès, en tot moment, per conèixer les tradicions de la Corona que havia aconseguit i intentà preservar-les a través dels seus actes i de les seves actuacions públiques, amb la pretensió, segurament, d'obtenir o de mantenir el favor dels seus súbdits, i en especial el dels sectors més propers i poderosos que l'envoltaven.

\footnotetext{
${ }^{23}$ B. PALACIOS, La coronación, pp. 219-221.

${ }^{24}$ Ibídem, pp. 217-218.

${ }^{25}$ Ibidem, pp. 216 i 242.
} 
Al llarg del seu regnat, les peticions d'informes als arxivers reials sobre com havien actuat els seus predecessors en circumstàncies concretes són múltiples, encara que moltes vegades es trobin doblement intencionades.

En relació amb la seva coronació, i encara que fos amb finalitats financeres, Ferran apel-là a la tradició, com veurem, en fer les demandes de coronatge, o també en preparar l'erecció de Girona en Principat, tot informant-se de les formalitats seguides pels anteriors monarques per nomenar Ducs de Girona llurs primogènits ${ }^{26}$.

Però ho féu igualment, per exemple, i algunes vegades referint-se directament a l'Ordinació de Pere el Cerimoniós, en sol-licitar a Sancho d'Ávila, el seu cambrer, que s'ocupés de fer la sella per a la coronació de la reina ${ }^{27}$; $o$ abans de decidir què en faria dels paraments i del cavall que havia cavalcat el dia de la coronacióo ${ }^{28}$; o per entrar a València o a Barcelona després d'haver-se coronat, encara que, en aquest darrer cas, amb un clar rerafons econòmic ${ }^{29}$.

\footnotetext{
${ }^{26}$ Durant la cerimònia de la coronació de Ferran d'Antequera, l'infant Alfons, el primogènit, rebé la dignitat de Príncep de Girona i el seu germà Joan la de Duc de Peñafiel. La intenció de Ferran era, en un principi, nomenar Alfons Duc de Girona, però els gironins s'hi oposaren al-legant antics privilegis $i$, més encara, quan, posteriorment, el rei es proposà erigir-lo a la dignitat de Principat; no pas sense problemes, el rei acabà, tanmateix, sortint-se amb la seva (cf. ACA, C., reg. 2403, fols. 166 v., 171 r. i 171 v. i reg. 2404 , fols. 18 v. -19 r., 24 v. i 82 v.).

27"Entenents en fer apperellar les insígnies de nostra beneventurada coronació e de nostra molt cara muller la reyna, vos pregam, dehim e manam que, com pus prestament porets, façats fer, a ops de la dita reyna, una bella cella de drap blanch d'aur, si trobar lo porets, si no de vellut o de domesquí, e un fre ab capçanes e regnes de seda, ab parxe e flocadures de ceda blancha ab fill d'aur, segons que en acte de coronació d'altres reynes en aquest regne és acustumat de fer, millorant-hi encara ço que serà possible"; ACA, C., reg. 2403, fol. 139 r. 1413, novembre, 16. Lleida.

${ }^{28}$ Ferran es dirigí, primer, a Guillem Oliver, "per çò com lo nostre cavalleriz pretén pertànyer-li per dret de son [o]ffici les sobrevestes del cavall que cavalcàvam lo jorn de nostra benaventurada coronació e los canonges de la Seu afermen pertànyer-se a ells lo dit cavall, e lo penoner e alferiz nostre les banderes e lo cavall que el cavalcava, vos manam que, tantost vos certifiquets si les dites coses consta per stil e ordinació de nostra casa o si en la coronació del senyor rey en Pere, avi nostre, de gloriosa memòria, fon axí usat (...)"; el mateix dia féu igual petició a Joan [Desplà] sobre "en la coronació del rey en Martí, oncle nostre, de gloriosa memòria, com se'n usà, ne si d'alguna de les dites coses fon feta smena a alcú dels damunt dits"; ACA, C., reg. 2403, fol. 174 v. 1414, març, 4. Saragossa.

${ }^{29}$ A la darreria de 1414, Ferran s'adreçà a Gabriel Gombau, canonge de la Seu de Barcelona, per "saber e ésser informats ab quina manera o solempnitat e ab quines cerimònies lo molt alt senyor rey en Martí, oncle nostre, de gloriosa memòria, entrà en la ciutat de València la primera vegada que y fou aprés que fou coronat". Com que creia que "vós sapiats e, segons se diu, dejats saber les dites coses", li demanà que "de les dites solempnitat e serimònies e de la forma e manera que $I$ dit senyor rey en Martí, oncle nostre, tench e servà, axí en vestits com en altres coses, en lo ingrés o intrament de la dita ciutat, nos scrivats e-ns
} 
Les notícies que tenim de la coronació de Ferran d'Antequera coincideixen perfectament amb el ritual descrit en l'Ordinació de Pere el Cerimoniós: Ferran I féu tots els possibles per seguir-lo al peu de la lletra, fins i tot quan la manca de temps o les circumstàncies li foren contràries ${ }^{30}$.

\section{LA DATA: CANVIS I TRASLlATS}

La coronació de Ferran d'Antequera tingué lloc a Saragossa el diumenge 11 de febrer de l'any 1414 i la de la seva muller, la reina Elionor, tres dies més tard, el dimecres dia $14^{31}$.

certifiquets, com pus breument porets, per vostres letres" (ACA, C., reg. 2386, fol. 84 r. 1414, desembre, 6. Montblanc). L'estiu següent, quan anava a trobar-se amb Benet XIII per a les Vistes de Perpinyà, estava interessat en l'entrada a Barcelona, però per motius clarament econòmics: "segons havem entès", deia, dirigint-se a Joan Desplà, "aprés que'Is molt il·lustres predecessors nostres reys e reynes d'Aragó retornaven a Barcelona feta lur coronació, los era feta festa en aquexa ciutat de Barcelona, axí com en lo primer ingrés d'aquella, perquè-us pregam, dehim e manam que, diligentment e secreta, vos informets si és axí. E si trobarets que axí sia, façats e procurets, ab los consellers e altres del Consell de Barcelona, que açò que haurien a despendre en la dita festa nos donen en diners per sustentació de nostre stat reyal e subvenció de les despeses que a present fem en lo camí o anada de Perpinyà passants per la dita ciutat de Barcelona. E si per la dita vostra informació trobarets no ésser costumat axí com dit és, no $n$ parlets gens, màs notificats-los que nostra molt cara filla, la principessa de Gerona, ven ab nós, perquè intimats-los lo seu novell aveniment induhint e persabint-los que la honren e la alegria de algun do graciós" (ACA, C., reg. 2391, fol. 24 r. - v. 1415, agost, 21. Santa Maria del Puig de València). Una setmana més tard, quan ja era a Cotlliure, volgué saber "segons l'Ordinació feta pel rei en Pere o en altra manera com millor pugui, en els camins o viatges marítims si les tendes o tendals o banderes, tant d'oriflama com d'altres, han de ser dels patrons o còmits o quin dret hi han de tenir" (ACA, C., reg. 2391, fol. 25 r. 1415, agost, 29. Cotlliure).

${ }^{30}$ Segons el cerimonial, la vigília de llurs respectives coronacions tant el rei com la reina havien de dirigir-se a la Seu vestits de blanc, símbol de castedat, i muntats dalt d'un cavall també blanc sense esperons (cf. Ordinació..., p. 272 pel que fa al rei i p. 305 per a la reina). Uns dies abans de la seva coronació, com que Ferran encara no havia aconseguit que li enviessin de Castella, eorum genitrix, els dos cavalls blancs que havia demanat, hagué de pregar al Papa que n'hi subministrés dos dels seus (ACA, C., reg. 2404, fol. 90 r. 1414, gener, 22. Saragossa).

${ }^{31}$ La crònica de García de Santa María, segons l'edició de D. Ferro, Le parti inedite, p. 123, parla, per la reina, del miércoles veinte y cuatro días de febrero. Es tracta, sens dubte, d'un error, ja que, el 1414, el 24 de febrer fou dissabte i, en canvi, el 14 fou dimecres ( $c f$. A. CaPPELl, Cronologia, Cronografia e Calendario Perpetuo, 6a. edició, Milà, 1988, p. 70), tal com indiquen altres dades que aporta la mateixa crònica (martes treze dias andados del mes de febrero es considera la vigília de la coronació de la reina i, posteriorment, es parla dels dies successiu com a viernes diez y seis días de febrero i lunes XIX días del mes de febrero; cf. D. FERRO, Le parti inedite, pp. 122, 127 i 129, respectivament). Per si en quedés algun dubte, la documentació ho reafirma, ja que, per exemple, el 16 de febrer el rei Ferran feia referència com a "beneventuradament celebrades" tant a la "solemnitat de nostra beneventurada coronació" 
La primera intenció del rei, després de ser proclamat, havia estat la de coronar-se l'abril de 1413, tal com, el gener d'aquell any, comunicà al merino i als prohoms de Saragossa per tal que comencessin a ocupar-se dels preparatius $^{32}$. Però els problemes polítics interns, i en especial l'alçament de Jaume d'Urgell, li ho impediren, de tal manera que, a contracor, es veié obligat a ajornar l'acte durant deu mesos.

Tanmateix, aquest compàs d'espera li permeté, després del setge $\mathrm{i}$ de la presa de Balaguer, que, amb tota la pompa i solemnitat, la seva esdevingués la coronació d'un rei triomfant que havia esclafat una rebel·lió, una coronació destinada a fer patent, davant dels súbdits, la seva grandesa, però, sobretot, a fer gala de la seva legitimitat, ja no només sancionada a Casp sinó també per la gràcia divina, que s'havia manifestat a través d'una victòria per la força de les armes sobre l'antic pretendent rival a la corona. És prou significatiu que, després de més de mig any de silenci, el monarca tornés a mencionar la seva voluntat de coronar-se l'agost de 1413, justament durant i des del setge de Balaguer ${ }^{33}$.

L'autèntica mobilització, doncs, començà un cop hagué reduït Jaume d'Urgell.

Des de mitjan novembre de 1413, el rei començà a concretar que, Déu volent, havem deliberat reebre les insignies de nostra benaventurada coronació en la ciutat de Çaragoça lo sendemà de la festa de Apparici primer vinent ${ }^{34}$. La primera intenció del monarca era, per tant, coronar-se el diumenge 7 de gener de 1414, l'endemà de l'Epifania, i que la coronació de la reina Elionor tingués lloc el diumenge següent, el dia 14. De fet, hom

com a la "de nostra molt cara muller la reyna" (ACA, C., reg. 2404 , fol. 29 r. - v. 1414 , febrer, 16. Saragossa).

32 "nós havemos muyto a coraçón, mediant la gracia divinal, celebrar la grant fiesta de la nuestra e solempna benaventurada coronació en el abril primero vinient"; ACA, C., reg. 2401, fol. 69 v. i fols. 69 v. - 70 r. 1413, gener, 25. Barcelona.

33" nós, pus hajam donada fi e conclusió a la execució que fem contra Jayme d'Urgell, lo quall tenim assatjat en Balaguer, hajam deliberat coronar-nos en la ciutat de Çaragoça"; $c f$. ACA, C., reg. 2403, fol. 68 r. i fol. 70 r. - v. (1413, agost, 22 i 23, respectivament. Setge de Balaguer), i reg. 2383, fol. 137 r. (1413, setembre, 25. Setge de Balaguer).

${ }^{34} \mathrm{ACA}, \mathrm{C}$, reg. 2403 , fols. 138 v. -139 r. i reg. 2383 , fols. 170 v., 170 v. -171 r. (1413, novembre, 13. Lleida); reg. 2383 , fols. 171 v. i 171 v. - 172 r. (1413, novembre, 14. Lleida); reg. 2403 , fol. 145 r. (1413, novembre, 24 . Lleida); i reg. 2383 , fol. 187 v. (1413, desembre, 13. Lleida). 
desplegà una gran activitat diplomàtica de cara a aquesta data i la casa reial envià múltiples cartes $\mathrm{i}$ invitacions per comunicar-la als convidats ${ }^{35}$.

Però, a desgrat de la intensitat dels preparatius, els problemes econòmics $\mathrm{i}$ d'organització obligarien el monarca a retardar la cerimònia diverses vegades: a mitjan desembre, fou traslladada al 21 de gener $\mathrm{i}$, posteriorment, encara fou endarrerida, successivament, fins al 28 de gener, fins al 4 de febrer i fins a l'11 de febrer, la data definitiva.

La correspondència que coneixem manté la previsió inicial, del 7 de gener, fins a l'inici de desembre. Aleshores, Ferran ja devia començar a plantejar-se l'ajornament de la festa, que consta, per primer cop, però encara sense una data concreta, en una carta del dia 13 adreçada als jurats i prohoms de Morvedre ${ }^{36}$. Quatre dies més tard, ja havia decidit celebrar-la el diumenge 21 de gener $^{37}$, mantenint la coronació de la reina el diumenge següent a la pròpia.

A aquelles alçades, els consellers de Barcelona ja havien elegit els missatgers que assistirien a la cerimònia, però, tot i amb això, ja es devien témer algun canvi, puix que, abans del 19 de desembre, havien demanat al rei que els certifiqués, clarament e certa, si la jornada (...) assignada a la dita coronació serà (...) proragada. Ferran els contestà dient-los que,

co[n]siderat que les cosas necesàries a la dita solemnitat bonament no hagueren aquell compliment que $s$ pertany a la jornada per nós assignada, atesa la brevitat del temps havem prorogada la dita jornada a XXI de janer

\footnotetext{
${ }^{35}$ ACA, C., reg. 2383, fol. 174 r. - v., 2 documents (1413, novembre, 20. Lleida); reg. 2439 , fols. 26 r. -29 r., 4 documents $(1413$, novembre, 23 . Lleida); reg. 2439 , fols. 1 r. -17 v., 13 documents (1413, novembre, 24. Lleida); reg. 2383, fol. 179 v. (1413, novembre, 26. Lleida); i reg. 2439, fol. 18 r., 2 documents (1413, desembre, 1. Lleida). Algunes de les cartes diuen, per error, dia 8 de gener en lloc de dia 7.

36"Per altres letres nostres vos havem scrit pregants-vos que alcunes notables persones d'aquexa vila fossen lo VII jorn de janer en la ciutat de Saragoça presents a nostra benaventurada coronació. Per ço com, a present, la celebració de la dita nostra benaventurada coronació se diferexca, nos plau que $n$ trametre les dites persones sobresehiscats trossús de nós hajats altre manament en contrari"; ACA, C., reg. 2399, fol. 91 v. 1413, desembre, 13. Lleida.

${ }^{37}$ ACA, C., reg. 2439, fol. 24 r. 1413, desembre, 17. Lleida. Des de l'endemà mateix, 18 de desembre, el rei ja envià les primeres cartes als convidats per notificar-los el canvi de plans: "segons per altra letra nostra vos havem scrit, nós enteníem celebrar la festa de nostra benaventurada coronació lo setèn jorn de janer primer vinent. Emperò, sobrevinents alscuns arduus negocis en los quals nos cové vagar, la dita jornada havem prorogada fins al vint-e-un jorn del dit mes" (ACA, C., reg. 2439, fols. 20 r. - v. i 24 v. 1413, desembre, 18. Lleida; reg. 2439, fol. 21 r. 1413, desembre, 19. Lleida; reg. 2439, fols. 24 v. -25 r. 1413, desembre, 20. Lleida; reg. 2404, fol. 6 r. - 6 v., 4 documents. 1413, desembre, 31. Lleida; i reg. 2404, fol. 11 v. 1414 , gener, 3. Lleida).
} 
propvinent, que serà dimecres $(\text { sic })^{38}$, e tantós lo dimenge següent havem deliberat solemnitzar la festa de la coronació de nostra molt cara muller la reyna, com tantost l'altre dimenge propsegüent sia de la Septuagèsima. Perquè, notificants-vos les dites coses, vos pregam que los dits missatgers façats espetxar e que partesquen axí com se pertany e que sien ab nós en la ciutat de Çaragoça VIII dies ans de la festa de la dita nostra coronació $^{39}$.

A la primeria de gener de 1414 , les cartes enviades pel monarca donant ordres per als preparatius de la celebració comencen a demostrar un mal contingut nerviosisme; expressen constantment el poc temps que resta abans de la coronació i que ja no es pot perdre ni un moment més ${ }^{40}$. És prou significativa, com a exemple, la missiva adreçada a mestre Bernat Ferrer, l'argenter de la casa reial que feia la corona, a qui el rei demanava que treballés, si convenia, nit i dia ${ }^{41}$.

Els preparatius anaven a contra-rellotge, però Ferran havia assegurat incomptables vegades que un nou trasllat de l'acte era impossible. Això no obstant, el sis de gener ja havia hagut de tornar a claudicar: l'havia endarrerida una altra setmana, justificant-se tot afirmant que, occupats de alscuns affers arduus, nos ha covengut prorogar e havem prorogada la solemnitat de nostra benaventurada coronació al XXVIII jorn del present $m^{4} s^{42}$.

Com sabem, la coronació tampoc no fou el 28 de gener. Quan la majoria de convidats ja devien ser a Saragossa, Ferran encara es veié obligat a traslladar-la dues vegades més, per un total de quinze dies: del diumenge 28 de gener al 4 de febrer i, d'aquest, a la data definitiva ${ }^{43}$.

Anar més enllà hauria estat, ara sí, impossible: el 21 de febrer era Dimecres de Cendra. Les festes havien de durar uns deu dies, però no

\footnotetext{
${ }^{38}$ Es tracta, sens dubte, d'un error. Hem de llegir-hi diumenge. Altrament, a més, el text no tindria sentit, perquè parla de diumenge en diumenge.

${ }^{39} \mathrm{ACA}, \mathrm{C}$, reg. 2403 , fols. 169 v. - 170 r. 1413, desembre, 19. Lleida.

${ }^{40} \mathrm{ACA}, \mathrm{C}$, reg. 2404 , fols. 8 v. - 9 r. 1414, gener, 2. Lleida (2 documents).

${ }^{41}$ ACA, C., reg. 2404, fol. 87 r. - v. 1414, gener, 5. Lleida. Vegeu el text corresponent a la nota 162

${ }^{42}$ ACA, C., reg. 2404 , fol. 12 r. 1414 , gener, 6. Lleida.

${ }^{43} \mathrm{Ho}$ palesa una carta que reclama la presència i retreu el retard a Roger Bernat de Pallars: "la solempnitat de la nostra benaventurada coronació, la qual havíem disposada fer dicmenge a IIII del present mes, (...) nós hajam prorrogat (...) al XI dia del dit e dejús scrit mes de ffebrer"; ACA, C., reg. 2404, fols. 92 v. -93 r. 1414, febrer, 2. Saragossa.
} 
podien pas coincidir amb la Quaresma. Això explica, segurament, que la reina no fos coronada el diumenge següent al de la coronació del rei, tal com sempre s'havia previst, sinó entre setmana, per evitar la superposició dels festeigs amb el període de dejuni i abstinència.

\section{EL FINANÇAMENT:}

DEMANDES PER CORONATGE, NOVELL REGIMENT, NOVELLA CAVALLERIA I MARIDATGE

Bonifacio Palacios opina que, fins al 1410 , data de la coronació de Martí l'Humà, el cobrament del coronatge era de caràcter voluntari i que no és segur que, abans de la coronació d'Alfons el Benigne, es percebés aquest impost extraordinari. De fet, com que fins aleshores les coronacions no devien haver suposat una despesa excessiva, seria lògic pensar que, amb anterioritat, encara no existís. Les dues úniques coronacions que s'havien celebrat a Saragossa, les de Pere el Gran i Alfons el Liberal, havien tingut lloc en el marc de les Corts i, per tant, només en devien haver augmentat poc les despeses habituals. En canvi, des de la coronació d'Alfons el Benigne, l'augment de les despeses havia creat la necessitat de recursos extraordinaris. Però, paradoxalment, quan la festa de la coronació decaigué, ço és, a partir de Ferran I, el coronatge adquirí el caràcter tributari que Palacios qualifica de fixe $e^{44}$.

Ferran d'Antequera imposà i intentà cobrar de forma sistemàtica el coronatge $^{45}$. Però, encara que les fonts facin referència constant a les demandes de la coronació del rei, també parlen d'altres demandes que s'hi combinen o superposen i que són difícils de destriar de les de la coronació:

\footnotetext{
${ }^{44}$ B. Palacios, La coronación, pp. 221-222, 273 i 280 . Aquesta paradoxa fa que l'autor es pregunti fins a quin punt el cobrament del coronatge pogué ser un incentiu per afermar la festa de la coronació. Sobre el coronatge i maridatge a Mallorca a la segona meitat del segle XV i a la primeria del XVI, if. M. BARCELÓ CRESPí, Coronatge i maridatge (1458-1516), dins Homenatge a Antoni Mut Calafell, arxiver, Palma, 1993, pp. 17-33; l'autora afirma, tanmateix, que el coronatge "fou instituiit l'any 1424 pel rei Alfons el Magnànim" (p. 17).

${ }^{45} \mathrm{Ho}$ palesa no només la documentació de Cancelleria de l'ACA sinó també la de la secció de Reial Patrimoni, on s'han conservat quatre registres de comptes de la recaptació (ACA, RP, MR, reg. 2537 per la vegueria de Barcelona, reg. 2538 per al Rosselló i la Cerdanya, reg. 2539 cobrament del maravedí i 2540 obligacions de 1414).
} 
demandes per raó del novell regiment a l'inici del regnat ${ }^{46}$, demandes per la coronació de la reina, demandes per la novella cavalleria del Príncep de Girona $^{47}$ i, posteriorment, demandes pel maridatge d'aquest ${ }^{48}$.

És prou sabut que Ferran d'Antequera i, en especial, la seva muller, Elionor d'Alburquerque, que a Castella era coneguda com la rica hembra, disposaven d'àmplies fortunes $\mathrm{i}$ propietats familiars i personals. Però la llarga lluita de Ferran per accedir al tron, primer, i la guerra amb els urgellistes, després, les havien minades.

Des de ben aviat, Ferran I s'interessà per la conducta que els seus predecessors havien seguit per fer les demandes. Els primers indicis d'aquest interès coincideixen, certament, amb les primeres expressions de la voluntat de coronar-se, però és evident, també, que s'intensifiquen quan a les despeses dels enfrontaments de l'Interregne per aconseguir la corona s'hi sumen les ja massa feixugues despeses de la pacificació del Principat de Catalunya després de l'alçament de Jaume d'Urgell, si bé en el moment que ja se'n comença a entreveure el final.

Si, el 31 de juliol de 1413, des de Cervera i de cara a fer les demandes acostumades per a la seva coronació i per a la de la reina, Ferran

\footnotetext{
${ }^{46} \mathrm{Hem}$ localitzat diverses notícies, de la primeria de desembre de 1412 , de demandes exigides per Ferran I per raó del "novell e benaventurat regiment e per posar, Déus migençant, en bo e pacífich estament nostres feels sotsmeses e la cosa pública de nostres regnes e terres", que es justifiquen amb el fet que "nos convinga, necessàriament, fer molt grans messions e despeses"; ACA, C., reg. 2432, fol. 105 r. i següents. 1412, desembre, 3. Barcelona.

${ }^{47}$ El 20 de marc de 1414, des de Saragossa, Ferran comunicà a Joan de Montgay, batlle general del comtat d'Urgell, que havia decidit exigir demandes al comtat d'Urgell, al vescomtat d'Ager i a la resta de territoris que Jaume d'Urgell posseïa a Catalunya per raó de les excessives despeses fetes durant la seva coronació, la de la reina i la novella cavalleria del príncep de Girona, tal com ja havia fet amb la resta de súbdits i vassalls del Principat (ACA, C., reg. 2404, fol. 99 r., 2 documents). El 27 d'abril li aclarí que no volia que fes cap de les demandes als vassalls de l'església que poblessin aquelles terres (ACA, C., reg. 2385, fol. 80 r. - v.). El 8 d'octubre, des de Montblanc, feia nova referència a demandes pels tres motius en conjunt; a Girona i a Sant Feliu de Guíxols hi havia problemes per cobrar-les (ACA, C., reg. 2388, fol. 42 v.).

${ }^{48} \mathrm{El} 25$ de juliol de 1414 Ferran ja sol-licità a Diego Garcia, escrivà $\mathrm{i}$ tinent de les claus de l'arxiu de Barcelona, que li enviés, juntament amb el trasllat de les demandes de les coronacions dels reis Joan i Martí, els de qualssevol demandes per maridatges que ells mateixos haguessin fet, amb totes les instruccions al respecte que considerés necessàries (ACA, C., reg. 2405, fol . $14 \mathrm{r}$.). El mes de maig següent, les demandes ja s'havien fet efectives: "com nós, per rahó de la solepnització del matrimoni que, Déu volent, entenem a fer de nostre molt car fill, don Alfonso, príncep de Gerona, primogènit nostre, ab la molt alta dona Maria, filla del molt alt senyor don Enrich, rey de Castella, de bona memòria, hajam haüdes e'ns covinga a fer molt grans despeses a les quals, sens ajuda vostra e dels altres feels e naturals sotsmesos nostres, no poríem bonament satisfer (...)"; ACA, C., reg. 2432, fols. 115 i següents. 1415, maig, 22. València.
} 
ja havia ordenat a Lleonard de Sos que comparegués a la seva presència amb els quaderns o comptes de les quantitats percebudes en motiu de les coronacions del rei Martí i de la reina Maria i amb totes les instruccions necessàries per dur-les a terme ${ }^{49}$, quatre dies després, el 4 d'agost, ja foren trameses una trentena de cartes de creença, en blanc, a favor de Nicolau de Biota, escrivà de ració de la casa del rei, i de l'electe de Zamora, a qui Ferran va dirigir un memorial que contenia detalladament les instruccions que havien de seguir per fer les demandes al regne d'Aragó.

Lògicament, el monarca intentà, en tot moment, justificar la legitimitat d'aquestes imposicions, que, en el seu cas, fins i tot considerava més lícites que no pas en el dels reis anteriors ${ }^{50}$. Però aquesta opinió no era pas compartida per tothom, tal com gosaren exposar-li, amb sorpresa seva, els dos encarregats de recaptar-les al regne d'Aragó ${ }^{51}$.

${ }^{49}$ ACA, C., reg. 2383, fol. 106 r. Les peticions semblants, o d'altres més precises destinades a conèixer les demandes fetes en llocs concrets, són constants. El mes d'agost de 1414, per exemple, Ferran comunicà al mestre racional, Ramon Savall, que havia rebut, per mitjà de Pere Ram, totes les escriptures i comptes de les demandes de la coronació dels reis anteriors fins al rei Joan, però que necessitava, aleshores, els comptes i les escriptures de les demandes dels reis Joan i Martí; ACA, C., reg. 2407, fol. 16 r. 1414, agost, 22. Morella.

${ }^{50}$ Segons el memorial destinat a l'electe de Zamora i a Nicolau de Biota, aquests havien de procedir de la següent manera: "Primerament, les deven razonar que, per dreyto, justícia e costumbre general de todo el mundo ${ }_{\imath}$ los reyes pueden demandar e indicir col-lecta a sus súbditos por razón de su coronación. İtem, el dito senyor poría, por mera justicia, demandar e exigir aquestas demandas, pero, queriéndose haver entá ellos graciosament, los envía en messatgeros por demandarlas benignament. Ítem, que yassea a los reyes passados los naturales suos hayan notablement subvenido empero al dito senyor deven más subvenir por esguard que las expensas serán mayores, car los senyores infantes e los senyores otros qui son en Castiella hi han necessariament a venir, e forçadament vendrán con grand estado, assín que las expensas de la dita coronación haurán seyer mayores. E, por consegüent, los donativos e subvenciones deven ser mayores, car haurán a respondre los ditos donativos con las despesas. E dévese haver consideración que 1 dito senyor ha cessado fer todas exacciones de sus pueblos sinó tansolament de rendas e de demandas acustumbradas e, encara, en las demandas acustumbradas se ha havido benignament, la qual cosa sabet bien que no si fazía en los tiempos passados. Por tanto, los ruega e encarrega affectuosament que den e subvinguen al dito senyor, per la dita razón, liberalment e presta"; ACA, C., reg. 2403, fol. 51 r. - v. 1413, agost, 4. Setge davant Balaguer.

${ }^{51}$ La resposta que els donà Ferran fou molt contundent, però poc sensible a les necessitats dels súbdits, que devien ser prou evidents si tenim en compte que, en virtut d'aquestes, els col-lectors de les demandes gosaren contradir l'opinió del monarca. La resposta que ell els donà ho posa ben de manifest: "Scriván de ración: vuestra letra havemos recebida, fetxa a XIX del present mes d'agosto, e entendido lo que dizides de las demandas de nuestra coronación, que al electo de Çamora ne a vós no paresce que se deviessen fatzer agora per las grandes necesidades que han les gentes en exi regno, e que vernía sobre las que agora novament por nós havedes feyto (les del novell regiment?); a que vos respondemos que somos muyt maravellados de vós que considerades las grandes necesidades de los pueblos en exi regno e no parades mentes a las nuestras, qui, sens comparación, son muyt majores per las grandes cargas que 
En endavant, la mobilització fou total. La col·lecta de les demandes al Principat anà a càrrec de Joan Desplà ${ }^{52}$; del regne de València se n'ocupà el seu batlle general, Joan Mercader, a qui el rei va trametre un trasllat dels comptes de les demandes del rei Martíis; les demandes als comtats del Rosselló i de la Cerdanya les féu Joan de Ribesaltes ${ }^{54}$; del comtat d'Urgell i del vescomtat d'Ager se'n féu càrrec el seu batlle general, Joan de Montgay 55 i, de Mallorca, el procurador fiscal del regne ${ }^{56}$. A Aragó hi trobem, posteriorment, com a receptor general del regne per a les demandes de coronació de la reina, Francesc Ferriol ${ }^{57}$.

Diverses poblacions que es consideraven exemptes d'aquesta mena de demandes ${ }^{58} \mathrm{i}$, en especial, els llocs d'església ${ }^{59}$, hi reaccionaren aviat

tenimos en que ha muyto a nuestra honra e al bienavenir de nuestros regnos et tierres, porque vos mandamos que luego trabayedes e pongades cura que se fagan las ditas demandas por manera que d'aquelles e de todas otras que aver porredes e manlevar de qualquera part nos podamos socorer e ajudar"; ACA, C., reg. 2403, fols. 68 r. - v. 1413, agost, 23. Setge davant Balaguer.

${ }^{52}$ ACA, C., reg. 2402, fol. 20 v. 1413, agost, 13. Balaguer.

${ }^{53}$ ACA, C., reg. 2403, fols. 67 v., 68 r. i 70 r. - v., diversos documents (1413, agost, 22. Setge de Balaguer), i fol. 93 v. (1413, setembre, 16. Setge davant Balaguer).

${ }^{54} \mathrm{ACA}$, C., reg. 2383, fol. 189 r. - v. 1413, desembre, 15. Lleida. La comissió per a les demandes de la coronació de la reina li fou feta el 25 d'abril de 1414, des de Saragossa (ACA, C., reg. 2439 , fol. 34 v.).

${ }^{55}$ ACA, C., reg. 2404, fol. 99 r. 1414, març, 20. Saragossa. Vegeu la nota 47.

${ }^{56}$ ACA, C., reg. 2402, fol. 63 v. 1414, juliol, 7. Morella.

${ }^{57}$ ACA, C., reg. 2413 , fol. 173 r. - v. 1414, maig, 30. Saragossa. Les demandes per la coronació de la reina apareixen, normalment, conjuntament amb les del rei, però, com aquí, algunes vegades semblen recaptar-se de manera independent.

${ }^{58} \mathrm{Hi}$ hagué problemes, per exemple, a Perpinyà (ACA, C., reg. 2383, fol. 189 r. - v. i reg. 2404. fols. 6 v. - 7 r.), a Girona i Sant Feliu de Guíxols (ACA, C., reg. 2388, fol. 42 v. 1414, octubre, 8. Montblanc), a l'aljama jueva de Lleida (ACA, C., reg. 2405, fol. 52 v. 1414, octubre, 10. Montblanc), a Agramunt (ACA, C., reg. 2386, fol. 79 r. 1414, novembre, 30. Montblanc) o al castell i terme de Mataró (ACA, C., reg. 2389, fol. 49 r. 1415, febrer, 9. València). Segons una carta del 17 de desembre de 1415, aleshores encara es debatia si les ciutats i viles de Lleida, Tortosa, Perpinyà, Cotlliure i Puigcerdà havien pagat coronació dels reis precedents i, especialment, de les reines, sobretot en temps del rei Martí i de les seves esposes; per això Ferran demanà a Bartomeu de Gualbes, conseller $\mathrm{i}$ mestre racional, que s'encarregués d'esbrinar si tenien el deure de fer-ho i que, de passada, s'informés de si havien de pagar també les demandes fetes per raó de matrimonis dels primogènits. Pere Ram havia de fer el mateix en referència als llocs d'església (ACA, C., reg. 2408, fol. 83 r. 1415, desembre, 17. Perpinyà).

${ }^{59}$ Ferran I havia demanat a Lleonard de Sos que fes cercar, tant en l'ofici del racional com en l'arxiu reial, tots els actes i proves que pogués trobar "de com los lochs e vassalls de la esgléya havien pagat en demandes de coronació dels reys passats d'Aragó". Lleonard li havia enviat Joan de Déu amb alguns actes, quaderns i escriptures, però no es trobaven autentificats. Per aquest motiu, el monarca els hi retornà tot pregant-li que els fes autentificar $i$ tabellonar per 
en contra, oposant-hi privilegis i concessions dels anteriors sobirans, cosa que féu que, constantment, el rei hagués de sol-licitar comptes i escriptures dels seus predecessors. La majoria de vegades no degueren sortir-se amb la seva; però, sovint, el monarca deixà constància de la seva la perplexitat. Quan, per exemple, el batlle general del regne de València, Joan Mercader, li comunicà que $\cdot l s$ d'Oriola al $\cdot$ leguen privilegi que són franchs de demandes, ells mittents cascun any $M$ sous en la obra del castell, e axi mateix lo al-legue Alaquant, pagant $C$ florins tant solament, e axi matex mossèn Philip Boill, Ferran li contestà, convençut, que semblants privilegis no.s són poguts ésser atorgats per nostres predecessors en prejudici nostre e més de la cosa pública, la qual, axí com vós diets, deu ésser preferida a la privada ${ }^{60}$.

No ens pertoca, aquí, repassar exhaustivament les demandes de Ferran d'Antequera ni la destinació final d'aquests ingressos, però sí que cal remarcar que el monarca pressionà tant com pogué per cobrar-les, fins a tal punt que, a l'inici del regnat del seu fill, encara en persistia algun ressò. Tot i que, en teoria, la justificació de les demandes fossin les múltiples despeses de les festes de la coronació, no cal dir que les assignacions sobre les quantitats recaptades es feren sobre tota mena de despeses, que els teòrics ingressos de l'erari reial estaven hipotecats molt abans de ser exigits i que ben pocs foren destinats a la fi per a la qual, en principi, eren recaptats ${ }^{61}$.

La presència de lamentacions i de peticions de socors econòmic en la correspondència reial no és pas sorprenent, en la mesura que els problemes de liquidesa $i$ fins $i$ tot de solvència eren habituals i del tot reals. Però podien assolir extrems insospitats. Després de llur coronació, quan Ferran i Elionor decidiren estendre les demandes a les antigues possessions del comte d'Urgell, les cartes de creença trameses a les viles i llocs del comtat en favor de Joan de Montgay feien referència, com sempre, a les despeses excessives que s'havien hagut de fer a Saragossa, però afegien que aquestes havien arribat a tal punt que, fins i tot, impedien als monarques

notari públic per tal que es poguessin utilitzar com a prova de judici (ACA, C., reg. 2404, fol. 110 r. 1414, abril, 20. Saragossa). L'agost d'aquell mateix any, el rei també sol-licità les escriptures de les demandes fetes pel rei de Mallorca als prelats $\mathrm{i}$ altres eclesiàstics dels comtats de Rosselló i Cerdanya per coronacions i matrimonis (ACA, reg. 2407, fol. 16 v. 1414, agost, 22. Morella).

${ }^{60} \mathrm{ACA}, \mathrm{C}$, reg. 2403, fol. 93 v. 1413, setembre, 16. Setge davant Balaguer.

${ }^{61} \mathrm{El}$ març de 1416 , per exemple, encara tenim constància de deutes pendents per despeses fetes en draps d'or, de seda i pelleries de la coronació; ACA, C., reg. 2391, fol. 98 r. 
partir de Saragossa axi prestament com volriem ${ }^{62}$. I que la situació era més crítica del que ens podria semblar i realment prou greu com perquè els reis no poguessin marxar de Saragossa ho demostra una altra carta d'aquell mateix dia, adreçada al batlle general del regne de València ${ }^{63}$.

\section{LA GENEROSITAT REIAL: DONS I REGALS}

Però, lògicament, aquestes situacions, per extremes que fossin, no interferien en l'aparença de generositat i de proselitisme reial, i encara menys a l'entorn d'una data $\mathrm{i}$ d'un esdeveniment tan assenyalat. És prou significatiu que la crònica de Pérez de Guzmán tituli un dels seus capítols Cómo el rey dio de vestir a los continuos de su casa ${ }^{64}$.

Encara que tant la relació de Pérez de Guzmán com la crònica d'Álvar García ${ }^{65}$ exagerin, indubtablement, en la generalització i en la materialització dels dons reials, ja que, com veurem, el rei tingué problemes, i no només econòmics, fins $i$ tot per al propi abastiment de robes $i$ joies, també és cert que les notícies de regals a membres del clergat, de la noblesa, de la casa reial, de la casa de la reina o de la del príncep tampoc no escassegen.

Sabem que molts religiosos, procedents, sobretot, de monestirs peninsulars, reberen pagaments en concepte de llur manteniment pels dies que havien estat a Saragossa per la coronació ${ }^{66}$, i que succeí el mateix amb un grup d'ambaixadors granadins que hi assistiren.

\footnotetext{
${ }^{62}$ ACA, C., reg. 2404, fol. 98 r. - v. 1414, març, 15. Saragossa.

${ }^{63}$ "Axí com ja per altra letra vos havem scrit, nos havem proposat partir d'açí dins breus dies, mitgençant la ajuda de Déus. E com, per raó de la dita nostra partença, hajam necessari ésser accórreguts per vós de VI en VII mil florins per quitar e accórrer als officials e servidors nostres e de nostra molt cara muller la reyna, sens la qual cosa bonament partir no podem, pregam-vos affectuosament e de cor que, si jamés nos entenets fer plazer e servir, façats que, o de nostres rendes e drets o de les demandes de la coronació nostra e de la dita reyna, cara muller nostra, o per via d'empraments per vós de nostra part faedors a quelles assignacions que vós conexerets e veurets que fassen a fer, hajats los dits VI o VII mil florins, o al tot menys V mil florins, los quals, ab bon recapte e per certa persona, nos trametets de continent"; ACA, C., reg. 2404, fol. 98 r. 1414, març, 15. Saragossa.

${ }^{64}$ Crónica del rey don Juan, p. 359.

${ }^{65}$ Coronaciones, cf. M. Tintó, Cartas del baile, p. 309.

${ }^{66}$ Les notícies es concentren, especialment, al llarg del registre de Cancelleria 2413 (fols. 16 v. -17 v., 21 r. -22 v., 30 v., 31 r., 36 r., 38 v., 39 r., 41 r., 42 v...).
} 
Per un altre costat, les mullers de diversos membres de la família Cavalleria, per exemple, reberen pagaments per robes $i$ folres ${ }^{67}$; la llevadora de les camises reials i la seva filla, reberen diners per folrar les vestidures que el rei els havia regalat per vestir durant la coronació ${ }^{68}$; la muller del boteller de la reina també en rebé per vestir-se durant la festa ${ }^{69}$; i diversos mercaders $i$ drapers de Saragossa vengueren draps i pelleria a representants de la tresoreria reial, de la casa del primogènit o de la del merino de Saragossa per tal que els distribuïssin i donessin graciosament a domèstics i familiars ${ }^{70}$. En canvi, Anton de Pompín i Joan Muntanyes, andadors i verguers dels jurats de la ciutat de Saragossa que, de part d'aquests, havien presentat al rei, a la reina $i$ al primogènit una vaixella d'argent per a la solemnitat, reberen, per estrenes, 150 florins d'or d'Aragó ${ }^{71}$.

\section{ELS CONVIDATS}

El 24 de novembre de 1413, poc després d'haver decidit coronar-se el diumenge 7 de gener de 1414 i de coronar la reina el dia 14, la Cancelleria reial envià les invitacions per assistir a la coronació. N'hem computades, amb aquesta data, 335, repartides entre noblesa, clergat i universitats del Principat, de València i d'Aragó.

Com que la funció a la cerimònia i el tipus de participació a la festa depenia de la condició de cadascú, es distribuïren diverses tipologies de participacions.

Les invitacions a l'estament clerical s'adreçaren a 11 membres de l'episcopat ${ }^{72}$, a 18 abats i priors catalans i valencians ${ }^{73}$ i 13 membres del

${ }^{67} \mathrm{ACA}, \mathrm{C}$, reg. 2413, fols. $19 \mathrm{v} .-20 \mathrm{r}$.

${ }^{68} \mathrm{ACA}, \mathrm{C}$, reg. 2413 , fol. 53 v. 1414, gener, 31. Saragossa.

${ }^{69}$ ACA, C., reg. 2413 , fol. 54 r. 1414 , febrer, 8. Saragossa.

${ }^{70}$ ACA, C., reg. 2413 , fols. 63 r. -66 r. 1414, maig, 7. Saragossa.

"ACA, C., reg. 2413, fol. 68 v. 1414, abril, 19. Saragossa.

${ }^{72}$ Bisbes de València, Barcelona, Lleida, Tortosa, Mallorca, Girona, Urgell, Elna, Vic, Sogorb i a l'arquebisbe de Tarragona; ACA, C., reg. 2439, fol. 1 r. - v. Advertim per endavant, de cara a les notes successives, que la documentació pot incórrer en alguns errors pel que fa a la ubicació d'alguns dels invitats al Principat, al regne de València i al regne d'Aragó, però hem preferit recollir-los, a desgrat d'això, tal com apareixen als documents, sense modificar-ne ni l'ordre ni la intitulació. I que, evidentment, devien haver-hi, a més dels que 
clergat aragonès ${ }^{74}$. Les cartes, escrites en català a excepció de les dirigides als aragonesos, els sol-licitaven la presència a la Saragossa amb llurs vestiments pontificals, ja que haurien d'assistir a la missa durant la qual el rei rebria la unció i la coronación ${ }^{75}$.

Als nobles i comanadors, en canvi, se'ls exigia, únicament, llur assistència ${ }^{76}$. Foren enviades 51 invitacions a membres de la noblesa catalana $^{77}, 80$ a nobles $\mathrm{i}$ cavallers del regne de València ${ }^{78}, 42$ a nobles,

relacionarem en funció dels documents, altres convidats.

${ }^{73}$ Poblet, Santes Creus, Valldigna, Sant Bernat, Benifassà, Sant Joan de les Abadesses, Santa Maria d'Amer, Rodes, Roses, Vilabertran, Sant Martí del Canigó, Bellpuig, Villareal, L'Estany, Ager, Sant Cugat del Vallès, Santa Maria de Montserrat i Ripoll. ACA, C., reg. 2439, fol. 2 r. - v.

${ }^{74}$ Arquebisbe de Saragossa (sic), bisbes de l'església d'Osca i de Tarazona, abats de Rueda, Santa Fe, Piera, Beruela, San Juan de la Peña i Montearagón, priors dels monestirs de Santa Cristina, Santa María del Pilar de Saragossa i Sepulcre, i castellà d’Amposta; ACA, C., reg. 2439, fol. 12 r. - v. L'arquebisbe de Saragossa, García Fernández de Heredia, havia estat assassinat durant l'Interregne i la seu romangué vacant fins al 1415 (vegeu-ho a l'apartat 14, "L'ofici de la cerimònia religiosa"). Això podria indicar que la tramesa d'aquestes invitacions tenia, en bona part, un caràcter formulari.

${ }^{75}$ "Venerable religiós e amat nostre: En nós se doblen grantment creximents de plahers, alegries e goigs quant en nostres prosperitats e festes, operant la divinal clemència a intercessió de la gloriosa Verge Maria, no poch benaventurades, podem fer participants e $y$ són presents nostres feels e naturals sotsmeses, majorment aquells los quals sabem que-s deliten e troben singular plaer que nostra reyal excel-lència sia exalçada e decorada de grau e dignitat insignes. Com donchs nós, en nom de nostre senyor Déu e de la sua gloriosa mare, hajam deliberat, axí com ha ordonat la antigua saviesa, coronar-nos e pendre gloriosament e devota les sanctes uncció e insígnies de nostra benaventurada coronació <en la ciutat de Çaragoça, axí com fer se deu e han acostumat nostres predecessors $>$, de gloriosa memòria, lo primer dichmenge, que's comptarà lo VIII (sic) jorn del mes de janer, següent aprés festa de Epifania, e lo dichmenge aprés següent, axí matex, nostra molt cara muller la reyna, e en tals e tan excel·lents e solemnes festivitats nos pertanga ésser acompanyats de grans prelats e altres notables persones, havem deliberat e volem, axí com se deu fer, que vós entre-ls altres prelats de nostra senyoria siats ací ab nós per tal que mils sia ornada nostra solemnial festa de grans prelats e notables persones, segons que la excel-lència de nostra persona requer. Per çò, notificants-vos ab alegria les dites coses, vos pregam affectuosament que siats lo dit dia ab nós, per honrar, decorar e ennobleyir nostra solemne, gran e excel-lent festivitat. E portats vostres pontificals ornaments, com ab aquells revestit, ensemps ab los altres prelats de nostra senyoria qui aquí seran, hajats ésser assistent a la missa a la qual nós pendrem la uncció e coronació dessús dites"; ACA, C., reg. 2439 , fol. 2 r. - v.

${ }^{76}$ Les cartes són pràcticament similars a les adreçades al clergat; en varia només el fragment de la invitació, després d'esmentar la coronació de la reina, que, en el cas dels nobles, diu, només, "e en tals e tan excel-lents e solemnes festivitats nos pertanga ésser acompanyats de grans prelats e altres notables persones e haguéssem sobiran plaer que vós hi fóssets lo dia de la nostra solemnial festa damunt dita, pregam-vos affectuosament que hi siats"; ACA, C., reg. 2439, fols. 3 r. -4 r.

${ }^{77}$ Joan, comte de Prades; comtes de Pallars i de Cardona; vescomte de Castellbò; vescomtes d'Illa i de Canet, d'Evol, de Roda i de Perelló, cavallers; nobles Bernat de Cabrera, Hugó de Rocabertí, Jordi de Caramany, Ponç de Perellós, Ramon de Perellós, Jofre Gelabert de Cruïlles, 
cavallers i comanadors d'Aragó ${ }^{79}, 8$ a comanadors de Catalunya ${ }^{80}$ i 11 a

Berenguer Arnau de Cervelló, Pere de Cervelló, Galceran Alamany de Cervelló, Jordi de Queralt, Pere de Montcada, Guillem Ramon de Montcada, Bernat de Centelles, Bernat Galceran de Cruilles i Ramon d'Empúries, cavallers; Simó de Vallgornera, Seguer de Perapertusa i Ramon de Bages, cavallers; nobles Hug de Cardona, Antoni de Cardona, Ramon de Peguera, Joan d'Erill, Francesc d'Erill i Gelabert de Centelles; cavallers Otó de Perestortes, Francesc de Pau, Bernat d'Olms, Ramon Sagarriga, Francesc Bertran, Ramon de Torrelles, Joan de Vilamarí, Antic Almugàver, Pere Merles, Arnau de Foxà, Berenguer d'Olms, Riambau de Corbera, Francesc de Vilamarí, Galceran de Sentmenat, Pere d'Orcafa, Roger de Cabanyals, Mateu de Cardona, Dalmau Sacirera, Lluís de Requesens i Pere de Sentmenat (ACA, C., reg. 2439, fols. 3 r. -4 r.).

${ }^{78}$ Nobles Eimeric de Centelles, Pere de Centelles i Ramon de Vilaragut, cavallers; noble Eximèn Pere d'Arenós; Duc de Gandia; noble Pere Lladró; vescomte de Mançanera; noble Pere Maça, cavaller; cavallers Lluís Çabata, Joan Martínez de Lana, Pere de Vallterra, Francesc d'Esplugues, Joan Vives, Joan de Santfeliu, Francesc Corts, Bernat de Vilarig, Joan de Vallterra, Joan Escriva (posteriorment ratllat), Manuel Lançol, Jofre de Vilarig, Miquel de Gator (posteriorment ratllat), Hug de Bonastre, Pere Martí de Rueda (posteriorment ratllat), Pere d'Artés, Vidal de Blanes júnior, Guerau Bou, Domènec Mascó, Bernat Joan i Pere d'Esplugues; noble Jaume de Vilaragut; Vidal de Blanes, major, cavaller; cavallers Francesc Munyoz, Ferran Munyoz, Galceran de Santfeliu, Pere Mascó, Joan Gascó, Berenguer Vives i Bernat Escorva; noble Pere de Vilaragut, cavaller; Andreu Castellar, cavaller; nobles i cavallers Eximèn Pere de Calatayud, Lluís d'Abella i Berenguer de Vilaragut; cavallers Crispí de Valldaura, Joan Castellà, Pere Marrades, Pere Siscar, Jaume Castellar, Joan Fabra i Manuel de Ripoll; noble Francesc Mata, cavaller; cavaller Lluís de Vilarasa; noble cavaller Jofre de Tous; cavaller Lluís de Vilanova; noble cavaller Pere Sanç de Calatayud; cavallers Galceran de Castellví, Vidal de Vilanova i Joan Pardo; noble cavaller Bernat de Centelles; cavallers Francesc Soler, Pere Pardo, Pere Pardo menor, Joan de Vilanova, Lluís de Castellví, Azenar Pardo, Pere de Castellví, Gispert de Valleriola i Francesc d'Artés; nobles Jaume de Centelles, Felip Boïl i Gelabert de Centelles, cavallers; cavallers Jaume de Castellví, Pere Català, Joan Noderin de Moros, Lluís Carbonell, Lluís de Valleriola, Bernat de Puig i Lluís de Loriz; noble Francesc de Bellvís, cavaller; Francesc d'Arques, cavaller; i Comerano de Bet, cavaller (ACA, C., reg. 2439 , fols. 8 r. -9 r.).

${ }^{79}$ Joan Martín de Luna, cavaller; noble Arnaldo d'Alagó, major de dies, cavaller; noble Artal d'Alagó sènior, cavaller; nobles Joan Eiximèn d'Urrea i Joan Rodrigo de Luna, cavallers; noble Jaume de Luna, comanador d'Orria, de l'orde de Santiago; noble Pedro Ladrón, vescomte de Mançanera; dos comtes, amb el nom en blanc; noble Alvaro de Luna, comanador de Castellot de las Cuevas; cavallers Llop de Gorrea. Fernando de Heredia, Felip d'Orries i Joan de Bardagí; Joan Eiximèn Cerdan, cavaller, justícia d'Aragó; Antoni de Bardagí, cavaller; Blas Fernández de Heredia, cavaller, governador d'Aragó; Egidi Rodrigo de Lihori, camarleng del rei (amb anotació marginal obiit); Llop de Gorrea, cavaller, senyor del lloc de Santa Engràcia; Joan Dezlor, Martí de Pomar, Sancho Pedro de Pomar i Francisco Forcen, cavallers; Ramon de Mur, batlle general d'Aragó, cavaller; Pardo La Casta, cavaller, merino de Saragossa; Pedro Lope de Gorrea, Mateu Ram, Joan de Montcayo, Gonzalo de Linyan, Lorenzo de Heredia, Bertran Costo i Joan de Sesse, cavallers; comanadors de Montalban i Casp, cavallers; comanador d'Alcanyís; Lluís Costo, cavaller; comanadors de Montsó i de Cantavella; Pere de Pomar i Martí de Pomar, cavallers; Pedro Ferrández de Felizes; i Pedro Sancho d'Arles (ACA, C., reg. 2439, fols. 14 r. -15 r.).

${ }^{80}$ Comanadors de Masdéu, Corbins, Banyuls, Cervera, Mallorca, Térmens, Torres i Gardeny. Segueix un espai en blanc que podria indicar que la llista no estava acabada (ACA, C., reg. 2439 , fol. 12 r. - v.). 
comanadors del regne de València ${ }^{81}$.

El rei va escriure i convidar també, a part, diversos membres de la noblesa als quals volia armar cavallers, tot comunicant-los-ho ${ }^{82}$. Eren 15 catalans $^{83}, 17$ valencians $^{84}$ i 26 aragonesos $^{85}$.

Finalment, foren convocades les universitats $\mathrm{i}$ viles reials de la Corona, que havien d'elegir i enviar a Saragossa llurs representants ${ }^{86}$.

${ }^{81}$ Comanador major de Montesa, comanadors de Bexi, Benassal, Culla, Sueca i Ares, claver de Montesa, comanadors d'Onda, Perputxent, Cervera i Torrent (ACA, C., reg. 2439, fol. 10 r. - v.).

${ }^{82}$ "en tals e tan excel-lents e solemnes festivitats nos pertanga ésser acompanyats de grans prelats e altres notables persones e haguéssem sobiran plaer que vós hi fóssets. E, noresmenys, si aquell dia vós entre·ls altres volets ésser decorat de novella cavalleria per tal que mils fos ornada nostra solempnial festa e de molts cavallers, segons que la excel-lència de nostra persona requer, per çò, notificants-vos ab alegria gran les dites coses, vos pregam affectuosament que lo dit dia siats ab nós a la dita festivitat, apparellat segons que a vostre stat se pertany"; ACA, C., reg. 2439 , fols. 4 v. -5 r.

${ }^{83}$ El vescomte de Rocabertí, els nobles Bernat de Cruïlles, Bernat Roger de Pallars, Martí Joan de Cervelló, Bernat de Pinós i Pere d'Orcau, els donzells Ponç d'Oluja, Bernat de Talamanca i Berenguer de Talamanca, el noble Guerau d'Espès i els donzells Ponç de Malla, Bernat de Vilafranca, Galceran d'Oluja, Arnau de Blanes i Bernat de Vallguarnera (ACA, C., reg. 2439, fols. 4 v. -5 r.).

${ }^{84}$ El noble Ramon de Castellar, els donzells Joan Escriva i Jaume Escriva, el noble Eiximèn Pere d'Arenós (posteriorment ratllat), els donzells Francesc d'Esplugues, Ramon de Tous, Alfonso Rodrigo de Corella, Lluís de Loriz, Mantuel de Montagut, Manfred Escriva, Joan Pardo, Pere Çabata, Joan de Bellvís, Tristany d'Ager i Francesc Castellà, el noble Felip Boïl, donzell, i Bernat de Vallterra, donzell (ACA, C., reg. 2439, fol. 10 r. - v.).

${ }^{85}$ Pere Eiximèn d'Urrea, escuder, el noble Eximèn d'Urrea, escuder, els escuders Llop Eiximèn d'Heredia, Jaume Eximèn Cerdan, García Munyoz de Pamplona, Berenguer de Bardagí, Fernando de Sayas, Joan Escorvo i Pedro Martínez de Rueda, el noble Joan d'Ixer, Rodrigo Pedro d'Avarca, Juan Fernández de Heredia, Joan de Linyan, Pedro de Sesse, Arnau Pedro de Pamplona, Florenç Pérez de Pamplona, Sancho Latrás, Guirald de Bardagí, Martí Pere de Bardagí, Guirald d'Avarca, Blas Bardagí, Miquel de Gotor, Guillem Claver, Rodrigo de Mur, Garcia Pere de Pisa i Blas Ram de Bardagí d'Alcanyís (ACA, C., reg. 2439, fols. 15 v. 16 r.).

86" havem deliberat e volem, axí com és acostumat e-s deu fer, que algunes insignes e notables persones d'aquexa ciutat sien ab nós, segons que la excel-lència de nostra persona requer. Per çò, notificants-vos les dites coses, vos pregam affectuosament que elegiscats aquell nombre de notables persones que a vosaltres parrà que sien lo dit dia ab nós per honrar, decorar e ennobleyr nostra solemne e gran e excel-lent festivitat"; ACA, C., reg. 2439, fols. 5 v. -6 $\mathrm{v}$. 
S'adreçaren 27 cartes a llocs del Principat i de València ${ }^{87}$ i 16 a llocs d'Aragó ${ }^{88}$.

Quan la coronació fou traslladada al 21 de gener, el monarca notificà el canvi a pocs convidats, en especial a alguns membres de l'episcopat i als abats més destacats ${ }^{89}$. Comunicà també la nova data a alguns capítols catedralicis que prèviament no havien estat advertits i que, com les ciutats, havien d'enviar llurs representants a Saragossa, $i$ als diputats de València $i$ de Catalunya ${ }^{90}$.

Indirectament, el rei intentà, fins i tot, aconseguir la presència de Sant Vicent Ferrer, però sense èxit ${ }^{91}$.

El dia de la coronació, els membres de l'ofici del racional, de l'escribania i de la tresoreria reial també havien de ser a Saragossa ${ }^{92}$.

\footnotetext{
${ }^{87}$ Jurats i prohoms de les ciutats de València, Xàtiva i Sogorb; de les viles de Morvedre, Alzira, Oriola, Ontinyent, Vilareal, Castelló de la Plana de Borriana, Alpont, Castellfabib, Morella, Alacant i Cervera; de la ciutat de Manresa; paers i prohoms de la ciutat de Lleida; cònsols $\mathrm{i}$ prohoms de la ciutat de la Seu d'Urgell; jurats i prohoms de les ciutats de Vic i de Tarragona; procuradors i prohoms de la ciutat de Tortosa; consellers i prohoms de la ciutat de Barcelona; cònsols i prohoms de la ciutat d'Elna; jurats i prohoms de la ciutat de Girona; $i$ cònsols i prohoms de les viles de Perpinyà, Puigcerdà, Vilafranca del Conflent i Cotlliure (ACA, C., reg. 2439, fols. 5 v. -6 v.).

${ }^{88}$ Jurats i prohoms de les ciutats de Saragossa i Daroca; de les comunitats d'aldees de Daroca; de la ciutat de Terol; de la comunitat de la ciutat de Terol; de la ciutat de Calataiud; de la comunitat de la ciutat de Calataiud; de la ciutat de Tarazona; de la comunitat de la ciutat de Tarazona; de les viles de Montalbán i d'Alcanyís; de les ciutats d'Osca, de Jaca i de Barbastre; de la vila de Tamarit de Llitera; i de la ciutat de Santa Maria d'Albarracín (ACA, C., reg. 2439 , fol. 17 r. - v.).

${ }^{89}$ Per mitjà de dues cartes que van adreçades a l'arquebisbe de Saragossa (sic), al de Tarragona, als bisbes de Sogorb, Vic, Elna, Urgell, Osca, Girona, Mallorca i València, i als abats de Montserrat, Ripoll, Poblet, Santes Creus i Sant Cugat del Vallès (ACA, C., reg. 2439, fols. 20 r. - v. i 24 v. 1413, desembre, 18. Lleida). Sobre l'esment de l'arquebisbe de Saragossa, vegeu la nota 74 i l'apartat 14, "L'ofici de la cerimònia religiosa".

90 "vos pregam affectuosament que lo dit dia trametats algunes notables persones de aqueix capítol que sien ab nós per honrar, decorar e ennobleïr nostra dita solemne e gran festivitat, certificant-vos que'ns en farets assenyalat plaer e servir"; cartes dirigides als capítols i canonges de les esglésies de Tarragona, Barcelona, Girona, Elna, Vic, Tortosa, i als diputats de València i de Catalunya (ACA, C., reg. 2439, fols. 24 v. -25 r. 1413, desembre, 20. Lleida).

${ }^{91} \mathrm{El} 4$ de gener de 1414 , des de Lleida, li escrigué una carta dient-li que volia parlar amb ell i que li pregava que l'anés a trobar a Saragossa, cap a on ell es dirigia (ACA, C., reg. 2404, fol. $11 \mathrm{r}$.). Després de la coronació, el 6 de març, tornà a insistir-hi, en aquest cas dient-li clarament que la ciutat de Saragossa desitjava fermament la seva presència, ja que encara no hi havia estat per res (ACA, C., reg. 2404, fol. 94 v.).

${ }^{92}$ Carta a Ramon Savall, mestre racional, ACA, C., reg. 2404, fol. 80 v.; i cartes a Bartomeu Soler, Bernat Savall, Gabriel Sapila, Jaume Lendrich i Francesc Formós, de l'ofici de mestre racional de la cort, als escrivans reials Bartomeu Gras, Jaume Jutglar, Arnau Manyosa, Antoni Font i Pere Sobirats, a Arnau Sabastida, Bernat Fàbregues, Gilabert Roure, Arnau Roure i Romeu Pallarès, de l'ofici de la tresoreria reial, a Joan Assin, Joan Vilagut i
} 
Lògicament, Ferran manifestà un interès especial perquè hi fossin representats o hi assistissin alguns dels antics rivals pretendents a la Corona com el Duc de Gandia ${ }^{93}$ i Frederic d'Aragó, comte de Luna ${ }^{94}$ - o, també, altres membres de la casa reial d'Aragó, com ara Joana de Prades ${ }^{95}$.

Encara que les cròniques destaquin la presència, amb noms concrets, de nobles i prelats castellans, navarresos i sicilians ${ }^{96}$, les mencions directes que en tenim nosaltres són ben escasses ${ }^{97} \mathrm{i}$ no ens coincideixen, necessàriament, amb les dels llistats de les fonts cronístiques ${ }^{98}$. No sabem si els cavallers forasters foren convidats personalment, però el que sí podem dir és que, en tot cas, a la Cancelleria reial no n'ha quedat constància. Tampoc no hem trobat cap notícia documental de la presència de sicilians, però sí que, en canvi, genèricament, es mencionen diverses vegades castellans i navarresos.

Hem pogut constatar, igualment, la presència de moros del senyoriu reial de Medellín, del regne de Castella ${ }^{99}$, que podrien haver-hi assistit com

Joan Guissona, de l'escrivania del rei, i a Gabriel Rosset, escrivà del primogènit, ACA, C., reg. 2404 , fols. 80 v. -81 r. 1413 , desembre, 29 . Lleida.

${ }^{93} \mathrm{ACA}, \mathrm{C}$, reg. 2403 , fol. 150 r. 1413 , novembre, 27 . Lleida. El Duc de Gandia, fill de l'antic candidat, ja havia aparegut citat entre els nobles $\mathrm{i}$ cavallers valencians.

${ }^{94} \mathrm{ACA}$, C., reg. 2439 , fol. 24 r. (1413, desembre, 17. Lleida) i reg. 2404, fol. 6 r. -6 v. (1413, desembre, 31. Lleida); en aquest darrer cas, a més de dirigir-se al comte, s'adreçà també a Joan de Santfeliu, a Pero Ferrández de Felices, procurador general del comtat de Luna al regne d'Aragó, i, fins i tot, al bisbe de Sogorb perquè fessin tots els possibles perquè Frederic no hi faltés.

95" Cara cosina: com nostra excel-lent preheminència se delid molt que en los actes insignes per nós faedors, majorment ara, en l'acte de nostra gloriosa coronació, que molt prestament, Déu migençant, devem celebrar en la ciutat de Çaragoça, haja còpia de notables persones, specialment d'aquellas qui devallen de la nostra beneventurada casa d'Aragó, per çò, cara cosina, vos pregam affectuosament e de cor que, en la dita coronació (...) vingats personalment, per manera que en la dita coronació nos façats la honor que-s pertany. Certificants-vos que vostra venguda vos grehirem molt, e.ns en farets plaer e servir molt singulars"; ACA, C., reg. 2404, fol. 16 r. - v. 1414, gener, 6. Lleida.

${ }^{96} \mathrm{Cf}$. Coronaciones, citat per M. TINTÓ, Cartas del baile, pp. 307-308; tanmateix, i tot i que sigui prou extensa, García de Santa María reconeix que no pretén, en cap moment, ser exhaustiu en la relació.

${ }^{97}$ Tenim testimoniada la presència de nombrosos prelats $\mathrm{i}$ religiosos de diversos monestirs peninsulars, ja que, com hem dit, en iniciar el seu camí de retorn, la casa reial els satisféu les despeses dels dies que havien sojornat a Saragossa. Vegeu la nota 66.

${ }^{98}$ És el cas, per exemple, de Martín el Ciego, ministrer de corda del rei de Castella, a qui s'atorgà salconduït el 22 de febrer; ACA, C., reg. 2385, fol. 22 v.

${ }^{99} \mathrm{El} 21$ de febrer de 1414 Ferran I ordenà al seu tresorer, Ferran de la Cavalleria, que pagués a Abraem i a la seva dona Sogre, a Alicante i Mariam, a Iuçaf i Fàtima, a Ali i Fàtima, a Cossino i Axa, a Iuçaff i Fàtima, al seu germà Haame i a Ali Çaytam Audala, moros del seu 
a representants de les possessions castellanes del monarca però que, probablement, devien ser joglars més que no pas convidats pròpiament dits.

No cal dir, però, que no tots els invitats assistiren a la coronació ${ }^{100}$ i que alguns d'ells intentaren no fer-ho, contrariant, d'aquesta manera, la voluntat reial. A l'inici de gener de 1414, per exemple, Ferran va retreure al bisbe de Mallorca, Lluís, que encara no fos a Saragossa amb la resta de prelats de la seva senyoria i, com que el volia a l'acte, on deia li pertocava ser, li va ordenar que deixés de banda tots els afers que tingués pendents $\mathrm{i}$ que, abans del dia 21 d'aquell mateix mes, es presentés personalment, sens falta, a la capital aragonesa ${ }^{101}$. Tingué una actitud semblant el noble Roger Bernat de Pallars que, dos dies abans de la que se li havia anunciat com a data de la coronació, encara no havia anat cap a Saragossa, però que, gràcies a l'ajornament, encara podia ser-hi a temps ${ }^{102}$.

Alguns membres de la família reial també tardaren a donar notícies $^{103}$, però d'altres s'excusaren, com la reina de Navarra, a través

lloc de Medellín, del regne de Castella, 33 florins d'or d'Aragó per les despeses de llur manteniment d'onze dies, ultra els 157 florins 4 sous i 8 diners jaquesos que ja els havia manat donar a través de Diego Fernández de Sevilla (ACA, C., reg. 2413, fol. 20 v.). A la primeria de març, sabem que Marco d'Avila, correu, havia fet un viatge a Medellín amb cartes del rei per afers de la cort, per la qual cosa havia partit de Lleida, en direcció allí, el 31 de novembre de 1413 (ACA, C., reg. 2413, fols. 26 v. - 29 r. 1414, març, 5. Saragossa). I, de fet, les Coronaciones de Blancas parlen de "moços e moças" (lectura errònia de "moros e moras"?) "e christianos que vinieron a la dicha fiesta ansí de Medellín como de Valencia del Cid por honrar al dicho señor rey en la su fiesta"; $c f$. M. Tintó, Cartas del baile, p. 307.

${ }^{100} \mathrm{Per}$ absència del mestre de l'orde de Santa Maria de Montesa, per exemple, Ferran ordenà al comanador major, amb una carta signada personalment, que fos ell qui portés la bandera de sant Jordi el dia de la coronació, tot pregant-li, per tant, que aquell dia fos, sens falta, amb ell a Saragossa; ACA, C., reg. 2404, fol. 88 r. 1414, gener, 8 . Lleida.

${ }^{101}$ ACA, C., reg. 2404, fol. 11 v. 1414, gener, 3. Lleida.

102"Roger Bernat: l'altre dia vos scrivim per nostra letra pregant-vos que fossets açí personalment per ésser a la solempnitat de la nostra benaventurada coronació (...). E, segons vehem, vós no sots vengut, de la qual cosa nos maravellam e·ns desplau. On, com nós hajam prorrogat lo dia de la dita coronació (...) e hajam a no poch plaer vostra venguda entre los altres, per çò us pregam e encarregam que, encontinent, partiscats per venir açí a nós, per çò que, ans del dit XI dia de ffebrer (...) siats en esta ciutat. E per res açò no mudets o dilatets, com serà cosa de què 'ns farets singular plaer e lo contrari a nós desplauria"; ACA, C., reg. 2404, fols. 92 v. - 93 r. 1414, febrer, 2. Saragossa.

${ }^{103} \mathrm{El} 20$ de gener, ja des de Saragossa, Ferran increpà el seu oncle, el Duc de Gandia, amb qui havia acordat que s'ocuparia de fer anar a Saragossa, per a la coronació, dona Elionor, cosina de Ferran i neboda del Duc, perquè encara no sabia res de la seva partida ni de la seva arribada. Com que la festa encara no era a punt, li pregava de nou que hi proveís i que s'ocupés immediatament de què ella es disposés a assistir-hi; ACA, C., reg. 2404, f. 23 v. 
d'una carta del seu marit, per motius de salut ${ }^{104}$. A canvi, però, el navarrès envià a la coronació de Ferran alguns dels seus donzells de cambra ${ }^{105}$.

Segons fa constar Blancas, García de Santa María recull la presència de moros que avian venido al dicho señor rey por embaxadores de su rey moro de Granada, todos vestidos con albornoces e capuces e aljuvas moriscas e espadas ginetas de plata ${ }^{106}$. I la documentació demostra, en efecte, que, a Saragossa, durant la coronació, hi havia diversos ambaixadors granadins, que s'havien desplaçat a la Corona d'Aragó per negociar la pròrroga de la treva de $1413-14$, que vencia per l'abril ${ }^{107}$.

També assistí a la coronació, casualment, un representant del comte de La Marca, el senyor de Murells, que es trobava en terres catalanoaragoneses i que Ferran retingué a Saragossa perquè assistís a l'acte; en iniciar el seu camí de retorn, el rei demanà al comte que l'excusés per haver-

\footnotetext{
104 "Recebido havemos vuestra letra responsiva a la que vos havíamos embiada en razón de nuestra muy cara e muy amada senyora tía, muyer vuestra e muy cara e muy amada companyera, por a la fiesta de nuestra bienaventurada coronación. E, aquella entendida, vos respondemos que havemos havido e havemos, sabe Dios, grand anujo e desplazer del accident que ha acaescido a la dita reyna, nuestra muy cara e muyt cara senyora tía, companyera vuestra, la qual con muyt grand coraçón deseávamos e deseamos veer. Empero, pus a Dios no plaze agora por el accident de su persona, vierná tiempo, si plazerá a Dios e a la Vergen Santa María, madre suya, que en buena sanidat nos poremos veer e faular ensemble, segund nuestro coraçón desea" (ACA, C., reg. 2404, fol. 21 r. - v. 1414, gener, 18. Alfajarín). Es evident, però, que es comptava amb la seva presència, ja que es preveia, com veurem més avall, allotjar-la al palau de l'Aljafería.

105" Vos agradescemos muyto car nos havedes embiados vuestros donzelles de cámera por veer e mirar las fiestas e solemnitades que aquí se son fechas por razón de nuestra beneventurada coronación. E con ellos havemos havido grandes plazeres e alagrías en las dichas fiestas e solemnitades grandes, de las quales, cómo son passadas, a laor e servicio de Dios e de la Vergen María, su benaventurada madre, e a grand honra de nuestra reyal corona, los ditos donzelles, qui lo han visto todo, vos informarán largament"; ACA, C., reg. 2404, fols. 27 v. 28 r. 1414, febrer, 16. Saragossa.
}

${ }^{106}$ Coronaciones, cf. M. Tintó, Cartas del baile, p. 309.

${ }^{107}$ Relacionem àmpliament la presència dels granadins a Saragossa a la nostra tesi doctoral, R. SAliCrú i LluCh, Relacions de la Corona d'Aragó amb el regne de Granada al segle XV (1412-1458), Barcelona, 1996, vol. I, pp. 130-141, en curs d'edició en micro-fitxes. 
li ocasionat el sou retard ${ }^{108}$. I un cas semblant succeí amb Orleans, herald del Duc d'Orleans, que es trobava de pas camí de Portugal ${ }^{109}$.

En canvi, Arquimbau de Foix hauria volgut assistir a la coronació però no hi fou convidat, i Ferran hagué d'excusar-se per no haver-lo escrit al-legant imperatius temporals ${ }^{110}$.

\section{L'ALLOTJAMENT DELS CONVIDATS}

Des que començà a pensar en les festes de la seva coronació, Ferran d'Antequera també començà a tenir cura de l'allotjament dels futurs convidats.

A la fi de novembre de 1413, ja advertia els religiosos d'un dels monestirs saragossans, no sabem quin, de la imminent arribada del seu oncle, el duc de Gandia, a la ciutat, per tal que disposessin el seu allotjament al monestir, tal com ja havien fet altres vegades ${ }^{\prime \prime \prime}$.

Al cap d'un mes, les instruccions generals enviades al governador i justícia d'Aragó, al salmedina, als oficials i a la universitat de Saragossa eren molt més precises:

Como nós queramos, assín como yes razonable, que aquellos qui por fazer a nós honra e servicio serán e vindrán a la ciudat de Çaragoça per a la solemnidat de la nuesta beneventurada coronación, assín de los regnos de Castella e de Navarra como de nuestros regnos e tierras e de otras partes, sean bien acogidos e receptados en buenas posadas, cada uno segund su

\footnotetext{
108"Comte: vostra letra havem reebuda per lo senyor de Murells, ab la qual havem haüt pleer com per aquella havem sabut la bona disposició de vostra persona e vostra bon stat (...). Pregam-vos que hajats per escusat lo exibidor de les presents, missatger vostre, per la dilatació de la sua retornada, car nós lo havem detengut açí per çò que fos present a la solemnitat de nostra beneventurada coronació e de nostra molt cara muller la reyna, les quals, per la divinal clemència, havem en aquesta ciutat beneventuradament celebrades, on són stats presents los dits infants, nostres cars fills e filles, e gran part de nostres súbdits e feels submeses e vessalls, e molts barons e grans hòmens, axí del regne de Castella com de Navarra, segons lo dit vostre missatger vos porà reonar estesament"; ACA, C., reg. 2404, fol. 29 r. - v. 1414, febrer, 16. Saragossa.

${ }^{109}$ ACA, C., reg. 2404, fol. 96. 1414, març, 4. Saragossa.

110 "Responents-vos en çò que dehits de vostra venguda a nostra coronació, vos certificam que nós, ab gran voler, vos haguérem scrit a vós e molts altres qui som certs hagueren plaher ésser presents a la solemnitat de aquella, emperò la brevitat del temps no-u ha sofert"; ACA, C., reg. 2404, fol. 94 r. 1414, març, 6. Saragossa.

"'ACA, C., reg. 2403, fol. 150 r. 1413, novembre, 27. Lleida.
} 
stado e condición, por tanto a vosotros e a cada uno de vosotros dezimos e mandamos, expressament e de cierta sciencia, que compartades e dedes por posadas e barrios aquellas casas e carreras de la dita ciudat que a vosotros será bien visto.

E, car sobre la paga o loguer de las ditas posadas porían insurgir qüestiones e debados, de los quales fácilment se porían seguir bregas e danyos assín entre los hóspedes como entre los senyores e possehidores de las ditas casas o posadas, por ende, querientes tirar toda manera de occasión e escándalo entre ellos, mandámosvos que tatxedes e apreciedes e podades tatxar e apreciar las ditas posadas segund que a vosotros será bien visto, e podaes forçar, si necessario será, assín por imposición de penas como por execución de aquellas, e en otra manera, los vezinos e habitadores de la dita ciudat a receptar e recogir de los ditos hóspedes e tenir e servar la tatxación sobre esto fecha por vosotros ${ }^{112}$.

Uns dies després, el rei envià a Saragossa Benito Sánchez, aposentador reial, perquè s'ocupés de fer allotjar els oficials reials i els de la reina a la jueria i a la moreria de la ciutat ${ }^{113}$.

Com en el cas del duc de Gandia, l'allotjament d'alguns membres de la casa reial meresqué una atenció personalitzada, no només a Saragossa sinó també durant el trajecte. A l'inici de gener, Ferran comunicava als oficials i prohoms de totes les viles i llocs per on hagués de passar i on hagués d'aturar-se la infanta Isabel, que es dirigia a Saragossa seguint els manaments del monarca, que li fessin donar posades, vitualles i tot allò que necessités, i que li carreguessin a ell les despeses. També féu saber al batlle general del regne d'Aragó que havia disposat que, a Saragossa, la seva tia s'allotgés a les cases de Llop de Salmas i que, per tant, calia que les fes lliurar immediatament als enviats de la Infanta. Si, per ventura, es trobaven ocupades o ja havien estat preses per algú altre, havia de fer-les buidar tot seguit perquè en pogués disposar ${ }^{114}$.

${ }^{112}$ ACA, C., reg. 2403 , fol. 168 v. 1413 , desembre, 23. Lleida. Hi ha una carta, de la mateixa data, als jurats i prohoms de Saragossa (ACA, C., reg. 2403, fols. 168 v. - 169 r.) i una creença a favor de Ramon de Mur, batlle general del regne d'Aragó, i de Pero Núñez de Guzmán, encarregats de fer acomplir el memorial (ACA, C., reg. 2404, fols. 10 r. i $85 \mathrm{v}$. 86 r. 1414, gener, 3. Lleida).

${ }^{113}$ ACA, C., reg. 2404, fol. 3 v. 1413, desembre, 29. Lleida. El 2 de gener ho féu saber als encarregats de l'allotjament (ACA, C., reg. 2404, fol. 84 v.).

${ }^{114} \mathrm{ACA}, \mathrm{C}$, reg. 2404 , fols. 87 v. i 88 r. 1414 , gener, 8 . Lleida. 


\title{
9. L'ALLOTJAMENT REIAL
}

El palau de l'Aljafería de Saragossa, on havia d'hostatjar-se la família reial durant les festes $\mathrm{i}$ on havien de tenir lloc els banquets del rei $\mathrm{i}$ de la reina els dies de llurs respectives coronacions, va haver de ser objecte de reparacions i adequacions. De fet, aquesta fou una de les preocupacions més primerenques del monarca i és gràcies a això que sabem que, de bon principi, Ferran pensava coronar-se l'abril de 1413.

A la darreria de gener d'aquell any, el rei ja s'adreçà a Pardo de la Casta, merino de Saragossa, per expressar-li la necessitat que l'Aljafería estigués preparada, tot ordenant-li, per tant, que,

\begin{abstract}
de continent, fagades assín las cambras, tineles, patios, cosinas como las otras casas havientes necessidat reparación e adobo en la dita Aljafaría priestament adobar e reparar, haviéndovos assín diligentment en las cosas sobreditas que quada que nós seamos en aquella sea en tal e tan buena e perfeta disposición que seades digno de nós haver laor e remuneración ${ }^{115}$.
\end{abstract}

Per recobrir les parets del palau, el rei necessitava gran còpia de draps de paret francesos. Amb aquesta finalitat va enviar dotze cartes en blanc al batlle general del regne de València perquè, després d'esbrinar qui de València en tenia, fes que els hi prestessin, amb instruccions ben precises perquè no es malmetessin ni perdessin ${ }^{116}$. Però, al cap d'un mes, encara li reclamava les catifes e tapits e alfambres segons que per altres letres vos havem scrit ${ }^{117}$

Per un altre costat, el rei envià a Lleonard de Sos, lloctinent del mestre racional de la cort, sis cartes més, però aquestes adreçades directament a les reines Violant i Margarida, a mossèn Pere de Merles, a Esperandéu Cardona, a Bernat de Vinilagaya i al pronotari reial, que volia que li prestessin tots draps que hajen que sien bells ${ }^{118}$.

${ }^{115}$ ACA, C., reg. 2401, fol. 69 v. 1413, gener, 25. Barcelona; ed. J.M. MADURELL MARIMON, La Aljafería real de Zaragoza. Notas para su historia, "Hispania" XXI (1961), doc. 54 , p. 545. Madurell menciona i publica també altres documents relacionats amb les obres realitzades al palau abans de la coronació de Ferran I.

116 "posant en cascun cert senyal d'aquells da qui seran per tal que no.s pusquen cambiar"; ACA, C., reg. 2403, fol. 145 r. 1413 , novembre, 24. Lleida.

${ }^{117}$ ACA, C., reg. 2403, fol. 167 r. 1413, desembre, 23. Lleida.

${ }^{118}$ Havien de trametre'ls immediatament a Saragossa a l'escrivà de ració, Nicolau de Biota; ACA, C., reg. 2383, fol. 178 r. 1413, novembre, 24. Lleida. 
L'escrivà de ració també s'havia d'ocupar de fer astorar de buenas astoras de palla grossas todas las cambras, assín baxas como altas, que hajan a servir a nós e a la reyna e assimismo a la reyna de Navarra ${ }^{119}$, i de dur a terme altres reparacions per adequar l'allotjament dels infants. Alfons, el primogènit, s'havia d'hostatjar a la Torre del Vent, on calia posar draps blancs a les finestres; l'infant Joan, a la capella de Sant Jordi, que calia reconvertir en cambra i moblar adequadament; i els infants mestres, és a dir, Enric, mestre de Santiago, i Sanç, mestre d'Alcàntara, havien d'estarse a la cambra on hi havia hagut el camarleng, que calia emblanquinar. La resta del palau havia de romandre com a tinell ${ }^{120}$, segurament per disposar de prou espai per al banquet.

De cara a la coronació, al tinell reial s'hi van invertir, almenys, 484 florins en diversos tipus i tamanys fusta, que devia utilitzar-se tant per reparar-lo com per construir-hi les diverses estructures on, durant el convit, es desenvolupà l'espectacle ${ }^{121}$.

\section{LES ROBES: VESTIDURES I PARAMENTS}

La preparació, segons el ritual, tant dels hàbits que els reis havien de lluir durant la coronació com de la resta de paraments tèxtils que hi havien de concórrer fou un dels aspectes que més maldecaps provocà al monarca, un dels més complicats i difícils d'organitzar i, juntament amb les joies, un dels que més degué contribuir a l'ajornament de la data solemne.

La documentació que parla de robes i draperia relacionades amb la coronació és, lògicament, abundantíssima. Però, tot i que de vegades tenim

\footnotetext{
${ }^{119}$ ACA, C., reg. 2404 , fols. 4 v. - 5 r. 1413, desembre, 28. Lleida.

120 "Scriván de ración: Mandámosvos que, lugo vista la presente, fagades adreçar e arreparar en la nuestra Aljafaría la Torra del Viento, por quanto ha de posar en ella el primogénito, e fagades poner en las finestres sus panyos blanchos encerados. Assimismo, que fagades adreçar bien e enblanquear la cámera a du posava el camerlench, per çò que $\cdot y$ posen los Maestros, nuestros fijos. Assimismo, farets fazer, en la capella de Sent Jordi, una rixa e abaxo, fazia la tribuna, un apartimento de taules per a cámera de paramento, por quanto ha de posar ahí l'infante don Johan. E l'otro todo sia tinell. E en esto es mester que doneu grande eussía e diligencia, en tal manera que, quando nos hi siamos, lo fallemos todo bien adreçado"; ACA, C., reg. 2404, fol. 4 r. - v. 1413, desembre, 30. Lleida, ed. J.M. MADURELL, La Aljafería, doc. 56, p. 546 .

${ }^{121} S$ 'ha conservat un compte detallat amb els noms dels diversos proveïdors de fusta, les quantitats venudes i el seu valor a ACA, C., reg. 2413, fols. 61 v. - 63 r. 1414, abril, 27.
} 
informacions concretes de la utilitat de les teles que apareixen, molt sovint les notícies són poc explícites ${ }^{122}$.

Durant l'època imperial, els emperadors ja es feien coronar amb vestidures semblants a les del diaconat o sots-diaconat, com a mostra del desig de participar d'alguna manera de l'orde sacerdotal però sense equiparar-se al presbiterat. El ritual aragonès recollí aquesta tradició, però ben aviat la superà, intentant emular les vestidures dels graus més elevats del sacerdoci i, especialment, les del pontificat. Alba, dalmàtica, estola i maniple esdevingueren imprescindibles, per tant, en les coronacions dels reis d'Aragó ${ }^{123}$.

La dalmàtica que Ferran d'Antequera es féu obrar per aquella avinentesa fou una de les peces que més problemes li ocasionà. L'havia feta repartir, a meitats, per estalviar temps, entre Francesc Clar, brodador, i Joan Bertran, brodador reial, de Barcelona. Però, com que Clar no havia acabat o no havia fet l'obra com pertocava, calgué elegir tres mestres -un de part del brodador, un altre de part reial i un tercer per tots dos-perquè jutgessin quina part de l'obra calia acceptar i quina rebutjar. I el brodador reial, deixant de banda totes les altres feines, hagué d'acabar-la tot sol ${ }^{124}$.

La dalmàtica era obrada i brodada amb diversos fullatges, florons, gerres $i$ d'altres obratges menuts que són sobreposats ${ }^{125}$. Cada part es

\footnotetext{
${ }^{122}$ Trobem peticions, reiterades i disperses, de draps, a voltes de Melines, de Bruxel $\cdot$ les, de Perpinyà... El novembre de 1413 el rei ja havia encarregat al seu cambrer, Sancho d'Avila, cavaller, i al mercader Guillem de Fonollet que es fessin amb tots els draps d'or i de seda, atzeitunins, tafetans i velluts blancs que poguessin trobar, ja que serien necessaris per a la coronació. Amb els draps d'or $\mathrm{i}$ seda no hi hagué problemes, però sí, en canvi, per trobar atzeitunins, tafetans i velluts blancs (ACA, C., reg. 2403, fol. 143 r. - v. 1413, novembre, 22. Lleida). Els draps d'or i seda foren tramesos a Saragossa per cinc homes a cavall $i$ un porter (ACA, C., reg. 2404, fol. 3 r. 1413, desembre, 28. Lleida). Sobre el mercader Guillem de Fonollet, home fidel, conseller i informador aventatjat de Ferran d'Antequera, vegeu M. del TREPPO, Els mercaders catalans i l'expansió de la corona catalano-aragonesa, Barcelona, 1976, pp. 162-164, que el considera "l'expert en matèries italianes" de la cort catalano-aragonesa; A. BosColo, La politica italiana di Ferdinando I d'Aragona, Càller, 1954, pp. 133 i 156-158; i R. Salicrú i Lluch, Cartes de captius cristians a les presons de Tunis del regnat de Ferran d'Antequera, "Miscel·lània de Textos Medievals" 7 (1994), pp. 557 i següents. Vegeu també, més avall, el text corresponent a la nota 205.

${ }^{123}$ Cf. B. Palacios, La coronación, pp. 212-214.

${ }^{124}$ ACA, C., reg. 2402, fol. 36 r. (1413, agost, 29. Setge de Balaguer), reg. 2403, fols. 131 r. - 133 r. (1413, octubre, 16 i 26. Setge de Balaguer) i reg. 2383, fol. 168 v. (1413, novembre, 13. Lleida).

${ }^{125} \mathrm{~A}$ més de la dalmàtica, Joan Bertran també brodà, amb or i sedes, el camís i un gipó que el rei vestí el dia 11 de febrer. Amb l'ajut d'altres mestres brodadors, tardà dotze mesos en acabar-ho. Segons albarà de l'escrivà de ració, el cost total dels materials i de la feina realitzada
} 
trobava dividida en nou versos, cinc treballats amb fil d'or i quatre d'atzeituní carmesí. Aquests darrers duien brodats els fullatges i gerres de vellut de fil d'or sobreposades, perfilades sobre el vermell. La dalmàtica era folrada de terçanell de grana i orlada de franja de seda carmesina i de fil $d^{\prime}{ }^{126}$.

Jaume Ferrer, un perpunter barceloní que també havia intervingut en l'elaboració de la dalmàtica, va elaborar, a més, un setial, una manta de cavall i un dosser per al rei, i li va tallar, cosir i acabar els paraments de llit. La part central del setial era feta amb drap amb fullatges vellutats de verd i rosetes vermelles que duien puntes blanques al mig, amb barres d'or i de vellut carmesí divisades a la manera reial, orlat amb franja d'or i amb seda carmesina i folrat d'escodat vermell. La manta, que era feta a vies de fil d'or luquès i de vellut carmesí, era orlada amb una franja semblant i folrada de seda vermella. El dosser era de set versos, quatre de fil d'or i tres de vellut carmesí, orlat amb franja de seda vermella i de fil d'or i folrat de seda vermella $^{127}$.

El rei també es féu brodar unes sabates amb or i seda ${ }^{128}$.

La seva sella, de la que, malauradament, no tenim cap descripció com sí tenim de la de la reina, també era brodada ${ }^{129}$.

El primogènit lluí una sobrevesta de tafetà blanc i una cota de drap burell. El seu estandard era fet de la mateixa roba de tafetà blanc i la sella que muntava duia una coberta de terçanell del mateix color $^{130}$.

En canvi, per vestir els molts e diversos prelats axi de nostres regnes e terres com del regne de Castella que per a la solemnidat de la nostra benaventurada coronació sian açi presents e s'esperen, per a los quals seran necessàries moltes mitres, Ferran optà per escriure als diputats del General de Catalunya, que, segons havia sabut, en tenien empenyorades de molt

fou d'11.707 sous de Barcelona; ACA, C., reg. 2413, fol. 51 r. - v. 1414, abril, 3. Saragossa.

${ }^{126}$ ACA, C., reg. 2413 , fols. 45 v. -46 r. 1414, abril, 3. Saragossa. reina.

${ }^{127}$ Ibídem. Jaume Ferrer també va fer la túnica folrada de ras blanc de la coronació de la

${ }^{128}$ ACA, C., reg. 2404 , fol. 85 v. 1413 , desembre, 4. Lleida.

${ }^{129} \mathrm{El} 12$ de desembre el rei, en una carta a Guillem de Fonollet, feia referència a $l o$ ornament de la cella que.l amat cambrer nostre, mossèn Sancho d'Avila, faya brodar en aquexa ciutat [Barcelona]; ACA, C., reg. 2403, fol. 153 v. Per a la descripció de la sella de la reina Elionor, vegeu la nota 27.

${ }^{130}$ ACA, C., reg. 2413, fol. 33 r. - v. 1414, març, 12. Saragossa. 
belles, tot pregant-los que les portessin a Saragossa per tal que, si era necessari, poguessin servir el dia de la coronació ${ }^{131}$.

A través del batlle general del regne, Joan Mercader, València facilità al monarca la major part de les robes i ornaments utilitzats durant la coronació, de tal manera que, poc després de l'esdeveniment, quan el rei li demanà que li trametés vint alnes d'azeytoni carmesí vellutat, brocat d'aur, lo pus ricós e bell que posqués trobar, el batlle li hagué de contestar que en tota València no ha de la sort sinó una peça, prou sotil e no gens responent a açò que vós demanats, car tota la draperia semblant fon tramesa per los mercaders aquí per rahó de la vostra benaventurada coronació ${ }^{132}$.

A desgrat de les previsions i del llarg període de preparatius, el rei encara hagué d'acabar improvisant i treient d'on fos, a corre-cuita, allò que li mancava. A la darreria de gener, per exemple, suplicava al papa que li deixés tres draps de ras $^{133134}$.

Tampoc no fou fàcil aconseguir que Joan Mercader fes fer, a València, $X X X$ coxins de estrado de seda morisquos, màs que no sien grochs ${ }^{135}$. El batlle tingué dificultats per trobar la roba, ja que el groc era el color dominant de les teles disponibles. Per això va decidir enviar-li una mostra de la roba i de la forma dels coixins, perquè pogués decidir ell mateix ${ }^{136}$. Ferran li contestà que

\footnotetext{
${ }^{131}$ L'interès del monarca era prou viu com per aconsellar-los que, "si cas serà que vosaltres érets partits de Barcelona, de continent hi fets retornar alcuna persona de recapte ab letres vostres per forma que $n$ tot cas les dites mitres vinguen açí per a la dita festivitat"; ACA, C., reg. 2404, fol. 92 r. 1414, gener, 20. Saragossa.

${ }^{132}$ ACA, C., CR Ferran I, caixa 8, núm. 1314. 1414, març, 10. València; ed. M. TINTó, Cartas del baile, doc. 26, pp. 193-194.

133" Sanctissime ac beatissime pater: quia inter alia ornamenta solemnitzacioni nostre felicis coronacionis necessaria pluribus variisque et diversis pannis de raso indigemus, sanctitate vestra, fil iali recomendacione premissa, humiliter supplicamus quatenus tres ex suis dignetur nobis cum presente transmittere portitore"; ACA, C., reg. 2404, fol. 90 v., 2 documents. 1414, gener, 20. Saragossa.

${ }^{134} \mathrm{Com}$ ja havíem vist, també hagué de demanar al papa els dos cavalls blancs que havien de muntar ell i la reina, perquè els que havia encarregat a Castella no li havien arribat; vegeu la nota 30.

${ }^{135}$ ACA, C., reg. 2404 , fol. 1 v. 1413, desembre, 27. Lleida; citat per M. TinTó, Cartas del baile, p. 67.

136"Havets-me manat, senyor, que trameta a Çaragoça XXX coxinals de strado de drap de seda moriscs que no sien grocs. Yo no trop recapte sinó de draps en què ha molt groch, e per ço he acordat de trametre us mostra dels draps que trop (...); si $\cdot$ ls volets de semblant drap, scrivits-me'n cuytadament, car pens, ab la ajuda de Déu, que dins VIII jorns aprés que yo o sàpia seran fets. E havisats-me de la fayçó e manera que·ls volets, e si·y volrets entorn
} 


\begin{abstract}
haguérem plaer que de semblant drap se'n trobassen, ab tal que no·y hagués tant groch. Perquè, si no se'n poden haver, tremetets-nos la meytat de vellut blau de Lucha $\langle 0\rangle$ de Florença que tinga l'ordim de cànem e la maytat de vergat, ab passamà entorn e botons e flochs; la forma, en la mostra que ns havets tramesa la veurets (...). Dels coxins, emperò, si ab menys groch no se'n troben, trametets-nos-en semblants de la mostra una dotzena, e altre dotzena de vellut blau de Lucha o de Florença ab l'ordim de cànem segons dit és, e altre dotzena de vergat ${ }^{137}$.
\end{abstract}

Malgrat el canvi d'instruccions, el batlle hagué de tornar a escriure al rei dient-li que no trobava velluts blaus ne vergats i que, haüt bon consell de vostres servidors, atès que l temps no soffer dilació, havia decidit tallar XII coxins de la mostra que us tramis, e altres XII de vellut vert, e altres XII de vellut vermell, e fort breu seran a Çaragoça $a^{138}$, cosa que el rei no tingué cap més remei que acceptar ${ }^{139}$.

Els coixins de vellut vermell $\mathrm{i}$ de seda moriscos foren folrats amb tela gostança ampla vermella i els verds de vellut amb tela d'espinal vert. El vellut fou comprat a un mercader florentí, Pere de Sant Lopo, i el drap de seda morisc a Iucef Xupió i Ali Benxernit, mercaders sarraïns valencians. $\mathrm{Na}$ Jacmeta, esposa de Miquel Vidal, tintorer, s'encarregà de tallar-los, cosir-los, folrar-los i fer-los els passamans. Per enviar-los a Saragossa, tots trenta-sis foren posats en un caixó de fusta ${ }^{140}$.

Una bona part de les teles que foren necessàries s'utilitzaren per preparar el gran torneig, de cent contra cent, que el rei oferí a la reina després de la seva coronació. La meitat dels paraments es feren a València i els cent restants a Saragossa, a imitació dels primers. El rei en volia cent de verds i cent de vermells, però, com en el cas dels coixins, hi hagué

flocadura o passamà, ne botons als cantons. E tots seran forrats, jatssia que $\mid \mathrm{I}$ que us tramet no sia forrat"; ACA, C., CR Ferran I, caixa 5, núm. 758. 1414, gener, 4. València, ed. M. TINTÓ, Cartas del baile, doc. 22 bis, pp. 186-188.

${ }^{137}$ ACA, C., reg. 2404 , fol. 15 r. - v. 1414 , gener, 8. [Lleida]; citat per M. TıNTó, Cartas del baile, p. 67.

${ }^{138}$ ACA, C., CR Ferran I, caixa 8, núm. 1377. 1414, gener, 16. València; ed. M. TinTó, Cartas del baile, doc. 23, pp. 189-190.

139 "Dels coxinals, puys axí és, donats manera que prestament hajam aqueixs que fets fer"; ACA, C., reg. 2404, f. 22 v. 1414, gener, 19. Saragossa, citat per M. TinTó, Cartas del baile, pp. 67-68.

${ }^{140} \mathrm{ACA}, \mathrm{C}$, reg. 2412 , fols. 103 v. - 109 v. 1415 , abril, 24. València. 
problemes per trobar la roba, encara que en aquest cas perquè no se'n pogué localitzar la quantitat suficient.

El novembre de 1413 , el rei ja havia ordenat que es compressin cinquanta peces de tafetans vermells per a les cobertes dels cavalls que havien de participar al torneig ${ }^{141}$. El batlle general del regne de València els havia d'enviar a Nicolau de Biota juntament amb els altres paraments verds, ja obrats. Però, malgrat la insistència del rei $^{142}$, i com que fou impossible trobar tots els tafatans vermells que volia, hagué d'acabar consentint que $n$ fagades fer los $L$ vermellos e los $L$ cárdenos o de negres a imitació dels paraments verds ${ }^{143}$.

Els tafetans verds i vermells que serviren per fer, a la ciutat de València, els paraments de tornejar de cent cavallers i cavalls costaren, en total, 15.443 sous; foren subministrats per una desena de mercaders, entre els quals hi havia dos florentins. Setanta-cinc d'aquests paraments de tornejar foren obrats i pintats per diversos pintors, i els altres vint-i-cinc per un perpunter. Tots ells duien mostra de tela de Constança blanca ampla i foren folrats amb teles d'espinal. Els trameteren a Saragossa dins de deu caixes de fusta amb les juntes engrutades de canemàs verdúl ${ }^{144}$.

El novembre de 1413 Ferran també havia ordenat a Joan Mercader que fes fer, a València, vuitanta-cinc elms de tornejar, en un termini de quinze o vint dies com a màxim ${ }^{145}$. Però, finalment, se n'obraren norantavuit, de cuir de bou, perquè, abans de rebre les ordres, Mercader ja n'havia comprats vuit al lloriguer Miquel de Calatayud i els havia enviats a Nicolau de Biota, escrivà de ració, a Saragossa. Cinquanta els féu Francesc Marc, corretger, i els quaranta-vuit restants Domingo del Port, pintor. Dos armers, Bartomeu i Guillem Tarrac, en guarniren seixanta-vuit, és a dir, els dotaren de caretes, landes i de la resta de guarniments de ferro necessaris. Abrafim Gua, sarraí, guarní els altres trenta. Pere d'Eroles, capeller, es va encarregar de fer les dues-centes cimeres de feltre pels elms i paraments, cent per als

\footnotetext{
${ }^{141}$ ACA, C., reg. 2383, fol. 180 v. 1413, novembre, 25. Lleida.

${ }^{142}$ ACA, C., reg. 2403 , fols. 157 v. - 158 r., 159 r., 163 r., 167 r., 170 r. - v. 1413, desembre, 15, 16, 19 i 23.

${ }^{143} \mathrm{ACA}, \mathrm{C}$, reg. 2403, fols. 172 v. -173 r. 1413, desembre, 23. Lleida.

${ }^{144} \mathrm{ACA}, \mathrm{C}$., reg. 2412, fols. 103 r. - 109 v. 1415, abril, 24. València.

${ }^{145}$ ACA, C., reg. 2383 , fol. 170 v. 1413 , novembre, 13. Lleida.
} 
que es feien a València i cent més pels que feia fer el rei a Saragossa. Per fer els elms també foren necessàries dues moles fusta ${ }^{146}$.

Les cimeres dels elms duien plomalls de plomes de paó, i una dona anomenada Miquela s'encarregà de fer-ne setanta. El batlle general del regne de València li subministrà les plomes necessàries per fer-ne dos i la resta hagué de cercar-les ella mateixa. Pere Galvany féu vint-i-cinc plomalls més ${ }^{147}$.

Els elms i les cofes de vint-i-cinc dels paraments de tornejar foren conduïts a Saragossa embotits en llana blanca comprada a dos aluders. Els elms viatjaren dins de vuit sàrries grans, tretze sarrions de palma i trenta tronyelles d'espart ben lligades dins de caixes i les juntes de les caixes foren embenades $\mathrm{i}$ enguixades per un dels pintors ${ }^{148}$. Els plomalls $\mathrm{i}$ les cimeres, en canvi, viatjaren en cofres comprats especialment a mida per l'ocasió; a l'interior, els plomalls anaven embolicats en paper per çò que no.s gostassen $^{149}$.

Finalment, podem afegir que les mànigues i la falda de les cuirasses dels tornejadors eren fetes de drap d'or, amb tatxes i flocadures ${ }^{150}$.

Com que per fer els paraments dels tornejadors feia falta or, el batlle general del regne de València trameté a Saragossa tres mestres batifullers perquè hi poguessin batre in situ el dels cent paraments que es feien a la capital aragonesa. També hagueren de batre'n per a les banderes del rei i del primogènit. Amb aquesta finalitat, s'enviaren a Saragossa 4850 pans d'or partit, que viatjaren en llibres i posts ${ }^{151}$.

Durant les festes, l'infant Joan d'Aragó, duc de Peñafiel, tingué una taula de junyir a la ciutat. Els paraments dels seus cadafals i els pennons i banderes de la taula se li van fer de tafetà verd ${ }^{152}$; en canvi, les mantes del seu cavall eren de domasquí vermell i blanc ${ }^{153}$. Les quinze taules de junyir

\footnotetext{
${ }^{146} \mathrm{ACA}, \mathrm{C}$, reg. 2412 , fols. 103 r. - 109 v. 1415, abril, 24. València.

${ }^{147}$ Ibidem.

${ }^{148}$ Ibídem.

${ }^{149}$ Ibidem.

${ }^{150}$ ACA, C., reg. 2404, fol. 24 r. 1414, gener, 24. Saragossa.

${ }^{151} \mathrm{ACA}, \mathrm{C}$, reg. 2412, fols. 103 r. - 109 v. 1415, abril, 24. València

${ }^{152}$ ACA, C., reg. 2413, fols. 17 v. -18 r. 1414, febrer, 21. Saragossa.

${ }^{153}$ ACA, C., reg. 2413 , fol. 29 v. 1414, març, 5. Saragossa.
} 
amb llurs cadafals que el rei parà prop del Campo del Toro ${ }^{154}$ també foren guarnides de tafetà; una d'elles, guarnida especialment amb tafetà i amb cortines, fou per l'infant Alfons ${ }^{155}$.

\section{LES JOIES}

Segons la crònica de Pérez de Guzmán, Ferran d'Antequera va coronar-se amb una corona que li havia enviat la seva cunyada, Caterina de Lancaster, des de Castella ${ }^{156}$. Zurita diu que ho féu amb una corona que es féu obrar especialment per a l'ocasió i que la corona enviada de Castella fou la que el rei imposà a la reina Elionor ${ }^{157}$. García de Santa María, en canvi, i, per tant, també les Coronaciones de Blancas, diferencia una corona d'or que el rei s'havia fet fer, a Barcelona, expressament per coronar-se, que és detalladament descrita ${ }^{158}$, d'una altra corona, enviada per la reina Maria de Navarra, que serví per coronar la reina ${ }^{159}$.

No hi ha dubte que la d'Álvar García és la més versemblant, encara que, de ben segur, exageri en descriure la factura de la corona. I, per bé que no tinguem cap mena de notícia sobre la tramesa d'una corona per part de cap de les dues reines esmentades, no hi ha cap dubte que Ferran es féu fer una corona especial, nova, per a l'ocasió.

A la darreria d'octubre de 1413, ja havia ordenat a Bernat, argenter qui obra nostra corona, que, si encara no l'havia acabada, ho fes ràpidament, deixant de banda, si convenia, totes les altres feines ${ }^{160}$. A l'inici de desembre, comunicava a Ramon Desplà, ciutadà de Barcelona, que volia redimir diverses pedres fines i perles empenyorades que havien estat

\footnotetext{
${ }^{154}$ A la part sud-oest de la ciutat de Saragossa, el Campo del Toro i el de l'Hospital eren un raval de petites heretats, eres i espais buits alternats amb vivendes d'agricultors; $c f$. M.I. FALCÓN PÉREZ, Zaragoza en el siglo XV. Morfología urbana, huertas y término municipal, Saragossa, 1981, pp. 50-51.

${ }^{155}$ ACA, C., reg. 2413, fol. 33 r. - v. 1414, març, 12. Saragossa.

${ }^{156}$ Crónica del rey don Juan, p. 358. Vegeu, al respecte, I. MACDONALD, A Coronation Service

${ }^{157}$ J. de ZURITA, Anales, vol. V, llibre XII, capitol XXXIV, p. 385.

${ }^{158} \mathrm{D}$. FERRO, Le parti inedite, p. 106.

${ }^{159}$ Ibídem, pp. 106 i 124. M. TıNTó, A propòsit de la corona, docs. 1, 2 i 3, publica els fragments corresponents a la Crónica de don Juan, a Zurita i a les Coronaciones de Blancas.

${ }^{160}$ ACA, C., reg. 2403, fol. 131 r. 1413, octubre, 26. Setge de Balaguer.
} 
de Jaume d'Urgell car les dites perles e pedres se han a posar e encastar en la corona que nos fem fer per a la nostra benaventurada coronació, i li pregava que, tro a tant que nós enviem aquí certa persona per fer-vos pagament de la quantitat per la qual tenits en penyora les dites perles $e$ pedres fines, vullats mostrar aquellas als argenters qui obren la dita corona, perquè vejen los lochs e pusquen fer los encasts a on staran les dites pedres fines e perles ${ }^{161}$. Finalment, a la primeria de gener, encara tornava a adreçar-se a mestre Bernat Ferrer, argenter de la casa reial, recordant-li que, com ja sabia, lo temps de la nostra coronació és molt breu e ja no.s pot dilatar de XXI del present mes, per la qual cosa li pregava i manava expressament que traballets incessanment, nit e dia, en fer e obrar la nostra corona, per tal forma que nós hajam aquell-al temps ab tot bon acabament ${ }^{162}$.

Fer-se amb la pedreria necessària per elaborar la corona i les altres joies de la coronació no fou cosa fàcil. A més d'intentar recuperar les joies de Jaume d'Urgell venudes $\mathrm{i}$ empenyorades ${ }^{163}$, Ferran també intentà obtenir, per via de préstec i prometent retornar-les després de la festa, altres joies diverses. En principi, el tresorer reial era qui havia d'ocupar-se d'aconseguir totes les pedres $i$ perles que fessin falta ${ }^{164}$. El monarca li

\footnotetext{
${ }^{161}$ ACA, C., reg. 2403, fol. 152 v. 1413, desembre, 10. Balaguer; ed. M. TinTó, A propòsit de la corona, doc. 4 , pp. 146-147.

${ }^{162}$ ACA, C., reg. 2404, fol. 87 r. - v. 1414, gener, 5. Lleida. Posteriorment, camí de les Vistes de Perpinyà, part de les joies reials li foren robades $i$, entre elles, hi havia un dels florons de la corona: "partint certa roba nostra de Cothliure vers Perpenyà, prop Argilers és stada trencada una caxa, de nits, per algunes malvades persones (...) e d'aquella han furtat un floró de la nostra corona qui, ab lo ceptre e pom e altres joyells, era en la dita caxa. E creem que hajen pres algunes altres joyes, les quals encara no veem menys. Perquè us manam que, ab solícita diligència e cura, provehiscats e façats tenir asment, axí per argenters com en altra manera acustumada e que -us parega, si lo dit floró e altres joyes se poran trobar ne sentir e aquells qui'n hauran pres haver". La carta anava adreçada a Galceran Alamany de Cervelló, governador de Catalunya, a Joan Mercader, batlle general del regne de València, i a Jofre de Sentmenat, sots-veguer de Barcelona (ACA, C., reg. 2391, fols. 25 v. - 26 r. 1415, agost, 30. Vilanova de la Raó, prop de Perpinyà).

${ }^{163} \mathrm{~A}$ mitjan desembre de 1413 el rei envià a Barcelona el seu cambrer, Sancho d'Avila, perquè recuperés, en nom seu, totes les joies que havien estat de Jaume d'Urgell, majoritàriament venudes o empenyorades a Bernat de Torremorell. El rei volia que aquest anés a trobar el seu cambrer per mostrar-li "tots los lochs on són los dits joyels e axí metex los notaris en poder dels quals són les cartes de gràcies de les vendes dels dits joyells, endressant-lo e avisant-lo tant com a vós serà possible". Vuit dies després, el dia de Nadal, ja volia tenir-les totes en poder seu. F. VENDRELl, A. MASIÀ, Jaume el Dissortat, p. 175, també dediquen la seva atenció a la recuperació de les joies del comte d'Urgell.
}

${ }^{164} \mathrm{ACA}, \mathrm{C}$, reg. 2403 , fol. 149 r. - v. 1413, desembre, 2. Lleida. 
encarregà, per exemple, que recuperés un balaix $\mathrm{i}$ algunes perles i pedres fines del rei Martí que el comte de Cardona tenia en penyora de sis mil florins $^{165}$. El mateix comte també tenia empenyorada, per igual valor, la corona del rei Martí, però el tresorer, Joan Desplà, es va negar diverses vegades a obligar-se al comte per aquesta quantitat, de manera que Ferran li hagué d'ordenar, finalment, que, com que de totes totes volia tenir la corona el dia de la coronació, en fes l'obligació juntament amb el veguer de Barcelona, Antic Almugàver, amb Lleonard de Sos, lloctinent de mestre racional de la cort, $\mathrm{i}$ amb Guillem Colom, ciutadà de Barcelona ${ }^{166}$.

Des de ben aviat, el monarca també mostrà interès i intentà convèncer la universitat de València perquè li permetés lluir un fermall propietat de la ciutat ${ }^{167}$. Les repetides negatives dels valencians i la constant insistència del rei generaren una abundant correspondència ${ }^{168}$, però sembla que els primers hagueren d'acabar claudicant ${ }^{169}$.

En darrer terme, el rei també volgué recuperar aquella garlanda d'or e de pedres fines que la senyora reyna, de bona memòria, àvia nostra, lexà per a les mullers dels primogènits d'Aragó, encara que fos, només, per lluirla durant les festes. Per això manà al tresorer que, de nostra part, parlets ab los mercaders $o$ altres en poder de qui sie la dita garlanda que aquella nos

${ }^{165}$ ACA, C., reg. 2383, fol. 189 r. 1413, desembre, 16. Lleida.

${ }^{166} \mathrm{ACA}, \mathrm{C}$., reg. 2404 , fols. 17 r. -18 v. 1414 , gener, 11 . Fraga (3 documents).

167 "com lo dit senyor rey en breu (...) haja per deliberat fer e celebrar festa molt solemnial de la sua benaventurada coronació, a la qual covendran gran multitud de gents de grans stats, e lo dit senyor, en tanta e tan insigne festa e solemnitat, haja proposat de ésser ornat d'aquells pus bells arreus e ornaments que haver porà, per tal lo dit senyor prega molt affectuosament als dits justícia, jurats e consell de la dita ciutat que servesquen al dit senyor del fermall lo qual ha la dita ciutat per çò que de aquell se pusque amprar lo dit senyor en la dita festa", ACA, C., reg. 2383 , fol. 179 v. [1413, novembre, 26 . Lleida].

${ }^{168} \mathrm{ACA}$, C., reg. 2403, fol. 158 r. - v. (1413, desembre, 16. Lleida) i reg. 2404 , fols. 13 r. -14 v. (1414, gener, 8. Lleida, 5 documents). El fermall era penyora del rei Martí. Davant de tantes negatives dels valencians, Ferran acabà apel-lant a la necessitat de no fer el ridícul davant dels invitats estrangers ("per tal que en la nostra beneventurada coronació serà la reyna de Navarre, nostra cara tia, e moltes altres persones notables estrangeres e nós no som axí bé arreats en joyels com se pertanyeria a nosta honor") i dient que no estava en condicions de permetre's no tenir-lo el dia de la coronació: preferia que li deixessin el fermall per la festa que no pas que n'hi regalessin vint quan anés a València.

${ }^{169}$ En una carta del 19 de gener, des de Saragossa, al batlle general del regne de València, el rei assegurava que els jurats, consellers i prohoms de València intendunt nobis sub mutuo concedere unum gemale seu fermal. La mateixa carta ens el descriu com un fermal cum illis perulis, lapidibus preciosis ac margaritis et auro que in ipso sunt; ACA, C., reg. 2404, fol. 22 v. M. TinTó, Cartas del baile, pp. 76-80, dedica un apartat al fermall. 
presten per a la dita nostra coronació, amb el compromís de restituir e tornar aquella aprés la dita nostra coronacióo ${ }^{170}$.

Malgrat tot, a darrera hora i a corre-cuita, com succeí amb les robes i amb els cavalls blancs, el rei encara hagué de demanar ajut d'urgència, en aquest cas a la reina Violant ${ }^{171}$.

Sorprenentment, les notícies documentals dels preparatius de les festes de la coronació de Ferran d'Antequera no mencionen per res, a més de la corona, ni l'encàrrec ni la factura dels altres tres elements essencials de la cerimònia: l'espasa de la cavalleria, el ceptre i el pom, símbols del poder reial que el rei hagué de prendre, amb les pròpies mans, de sobre l'altar. No obstant, ha quedat constància que, poc després, Ferran s'enduia cap a Perpinyà, dins de la mateixa caixa que la corona i altres joies, els dos darrers ${ }^{172}$.

\section{LAA CERA: TORXES I BRANDONS}

Un dels aspectes que destaquen les cròniques de la coronació de Ferran d'Antequera és la gran quantitat de torxes i brandons que

\footnotetext{
${ }^{170}$ ACA, C., reg. 2404, fol. 11 r. - v. 1414, gener, 5. Lleida.

171 "Reyna molt cara tia: ja stants en Leyda havíem acordat scriure us que $n$ ns emprestàssets de les pus belles e fines pedres e perles que vós haguéssets per la nostra coronació e, pensants que hauríem bastament d'elles, no'ns curam amprar-vos-en. Emperò, com vejam are que no $n$ havem lo bastament que volríem o és necessari, pregam-vos, reyna molt cara tia, que, si may de res nos entenets fer pleer, vós, en aquest cas, nos emprestats les pus groces e millors perles e pedres fines que vós hajats, car, tantost solemnitzada la festa de la dita nostra coronació e de nostra molt cara muller la reyna, nós vos restituirem aquelles éntegrament. E trametets-nos aquelles prestament per alguna persona fiable, o les liurats a $n$ Leonart de Sors, lochtinent de mestre racional de la nostra cort, qui aquelles nos trameta de continent, axí com és necessari, attesa la brevitat del temps" (ACA, C., reg. 2404, fol. 92 v. 1414, gener, 24. Saragossa). El rei també donà notícia d'aquestes gestions al lloctinent de mestre racional: "Nós scrivim a nostra molt cara tia la senyora reyna dona Yolant pregant-la affectuosament que $n$ ns empreste, per a la coronació, les pus groces perles e pedres fines que haja. E, ja stants a Leyda, li-u haguérem scrit, més pensàvem haver assats bastament de les nostres. Perquè us pregam e manam que li donets la letra e de part nostra d'açò le tingats approp e, tantost que les hajats haüdes, si ella no acorda de tremetre-les per persona certa, vós tremetets-nos aquellas ab bon recapte e prestament, car ja veets que lo temps és tan breu que no sofer pus dilació" (ACA, C., reg. 2404, fol. 92 v. 1414, gener, 24. Saragossa).

${ }^{172}$ Vegeu la nota 162 . El rei, després de posar-se la corona, havia d'agafar el ceptre amb la mà dreta $i$ el pom amb l'esquerra. La crònica de García de Santa María tampoc no és gaire explícita sobre aquests dos elements: "el cetro en la cabeça d'él venía un balax tan grande como un huevo de paloma" $\mathrm{i}$ el pom era "una mançana de oro muy gruesa, tan grande como un huevo de grifos, con una cruz de oro por encima"; cf. D. FERRO, Le parti inedite, pp. 106-107.
} 
il-luminaren, com si fos de dia, tots els actes de les festes, des de la comitiva de la vigília des de l'Aljafería a la Seu fins al banquet posterior a la cerimònia. Encara que les notícies no siguin, precisament, massa abundants. és de destacar que, des de bon principi, fou una de les preocupacions del monarca. Aconseguir una bona il luminació no era pas quelcom irrellevant.

A l'inici de desembre de 1413 , el rei ja ordenà al batlle general del regne de València que s'encarregués de trametre, en el termini més breu possible, la cera a Saragossa, per tal que hi hagués el temps necessari per fer-ne torxes i brandons abans de la festa ${ }^{173}$. El batlle va comprar, a València, quinze càrregues $i$ vuit lliures de cera groga, que fou traslladada en sarrions, ben lligada amb fils i cordes, des del pes reial fins a casa d'un mestre que s'encarregà de refondre-la amb la finalitat de fer-ne menys pans i perquè fos més senzill traslladar-la a Saragossa. A més, Joan Mercader també va comprar cinc càrregues, dues roves i catorze lliures de cera blanca, tramesa a Saragossa en sacs de cànem, sarrions de palma i tronyelles d'espart. Les cinc càrregues de cera blanca foren conduïdes a Saragossa en cinc atzembles per Famet Jeofar i Ali Carim i les quinze de cera groga en quinze atzembles més, que també conduí fins a Saragossa un altre sarraí, Mahomat Benamir ${ }^{174}$.

El comprador de la casa del primogènit s'encarregà de fer pintar dos-cents brandons rodons amb els senyals reials de Sicília ${ }^{175}$.

\section{L'ENTRAda a SARAgossa}

L'entrada del rei a Saragossa, abans de coronar-se, era també un acte solemne, subjecte a ritual.

Ferran era, abans, a Lleida. Des d'allí, a la fi de desembre, va escriure al primogènit per fer-li saber que pensava sortir-ne el dimarts dia dos de gener per fer dreta via cap a la capital aragonesa. Com que volia que hi entressin plegats, li pregà que fos a Alfajarín, a tres llegües de Saragossa, o a La Pobla, a dues llegües, el divendres dia 5, on el monarca tenia previst

\footnotetext{
${ }^{173}$ ACA, C., reg. 2403, fol. 151 r. 1413, desembre, 5. Lleida.

${ }^{174} \mathrm{ACA}, \mathrm{C}$, reg. 2412 , fols. 103 r. - 109 v. 1415 , abril, 24. València.

${ }^{175}$ ACA, RP, MR, reg. 611 , fol. 35 r. 1414, febrer.
} 
arribar aquell dia ${ }^{176}$. Tres dies més tard, havent ja rebut resposta del seu fill, rectificà dient-li que no seria a Alfajarín fins el dissabte dia 6 i que calia que ell l'esperés allí ${ }^{\prime \prime}$. Però, el dia 8 de gener, Ferran encara era a Lleida, d'on, segons les cròniques, partí el dia $10^{178}$; l'endemà, el dia 11 , era a Fraga ${ }^{179}$.

Un cop hagué pres la decisió d'anar directament des de Lleida cap a Saragossa, comunicà a la universitat d'Osca que no s'hi deturaria, com havia promès anteriorment; tot demanant excuses als justícia, jurats $\mathrm{i}$ prohoms del lloc, els prometé que hi faria estada tan aviat com li fos possible ${ }^{180}$.

A la primeria de gener de 1414 hi hagué grans pluges que feren augmentar de forma considerable el cabdal del riu Ebre. Per això, el dia 5, prescindint de les instruccions anteriors, Ferran demanà al seu fill Alfons que, si havia pogut atravessar el riu, l'esperés a Alfajarín; que, si no ho havia fet i no hi havia perill, l'atravessés i l'esperés allí; però que, si suposava que n'hi havia, anés de dret a Saragossa i que, quan ell hi arribés, ja sortiria a trobar-lo ${ }^{181}$. Com que, en efecte, l'infant li contestà que creuar el riu era perillós, el seu pare hagué de conformar-se amb la darrera opció $^{182}$.

Ben a última hora, el rei va escriure a Nicolau de Biota ordenant-li que, com que volia que les seixanta llances de la seva guarda entressin amb ell a la ciutat d'una lliurea, fes fer, amb drap de Bristol o del mateix tipus, seixanta jornees de tres trossos, un de vermell a la capçana, un altre de verd al mig i un altre de color blanc a les faldes, i que les fes folrar de tela. Li va manar, lògicament, que agafés tants sastres com pogués trobar perquè volia que fossin fetes en un punt i que les hi enviés un dia abans de la seva entrada juntament amb seixanta llances perpuntades dels mateixos colors ${ }^{183}$.

${ }^{176}$ ACA, C., reg. 2404 , fol. 3 v. 1413, desembre, 29. Lleida.

${ }^{177}$ ACA, C., reg. 2404 , fol. 83 v. 1414, gener, 1. Lleida.

${ }^{178} \mathrm{Cf}$. J. de ZURITA, Anales, p. 384, i Crónica del rey don Juan, p. 358.

${ }^{179} \mathrm{ACA}, \mathrm{C}$, reg. 2404 , fols. 17 r. -18 v. 1414 , gener, 11. Fraga.

${ }^{180} \mathrm{ACA}, \mathrm{C}$, , reg. 2404 , fol. 10 v. 1414 , gener, 2 . Lleida.

${ }^{181}$ ACA, C., reg. 2404, fol. 87 r. 1414, gener, 5. Lleida.

${ }^{182} \mathrm{ACA}, \mathrm{C}$, reg. 2404 , fol. 12 r. - v. 1414 , gener, 6. Lleida.

${ }^{183}$ ACA, C., reg. 2404, fol. 15 r. 1414, gener, 8. Lleida; citat per M. Tintó, Cartas del baile, p. 70, notes 83 i 84 . Un cop més, la documentació coincideix prou bé amb la crònica de García de Santa María: "e los que ivan con el rey (...) ivan todos vestidos de librea del rey, que 
Amb aquestes presses, per Nicólau de Biota fou una sort que, de camí cap a Saragossa, la comitiva reial hagués d'aturar-se a Campdàsens per indisposició de la reina. Davant d'aquest imprevist, els mancaren queviures i Ferran hagué d'escriure als prohoms de Fraga per tal que, de continent, nos façats venir les més adzembles que porets carregades de pa, viures. fruytes e altres coses a la dita nostra cara muller e a las gens qui són ab ella necessàrias ${ }^{184}$.

L'infant Alfons tampoc no pogué ajustar-se a les previsions. El 14 de gener escrivia al seu pare per excusar-se de no poder ser a Saragossa el dia assenyalat, perquè el fort vent i la gran crescuda de l'Ebre encara li impedien creuar-lo. L'endemà mateix, se li tornava a adreçar per saber, finalment, on volia que l'esperés, a Pina, a Alfajarín o a La Pobla ${ }^{185}$.

Tal com diu Zurita, abans d'arribar a Saragossa el rei passà per Pina; però, en canvi, no pot ser cert que hi entrés el 15 de gener, com diuen tant el cronista com les Coronaciones ${ }^{186}$, perquè el dia 16 , des de Pina, comunicava al primogènit que la seva intenció era entrar a Saragossa el següent dimecres, és a dir, l'endemà mateix, dia 17, al matí. I, finalment, Alfons sortí a trobar-lo entre La Pobla i Saragossa ${ }^{187}$.

\section{L'OFICI DE LA CERIMÒNIA RELIGIOSA}

El 1205, la butlla d'Innocenci III va convertir Saragossa en escenari de les coronacions reials. Com que entre els estats de Pere el Catòlic només Aragó tenia qualitat de regne, això exclogué les grans ciutats catalanes $i$ facilità l'elecció de la ciutat aragonesa com a capital. A l'origen, per la seva primacia, els encarregats de materialitzar la coronació havien de ser els arquebisbes de Tarragona. Però, des que, el 1319, Saragossa fou erigida

era verde e blanco e colorado, barreadas las ropas"; Coronaciones..., cf. M. Tintó, Cartas del baile, p. 305.

${ }^{184}$ ACA, C., reg. 2404 , fol. 21 v. 1414, gener, 13. Campdàsens.

${ }^{185}$ ACA, C., CR Ferran I, caixa 8, núms. 1393 i 1387; citades per E. SARASA, Fernando $I$, p. 19 , nota 1 .

186J. de ZURITA, Anales, p. 384 i Coronaciones, cf. M. Tintó, Cartas del baile, p. 305

${ }^{187}$ ACA, C., reg. 2404 , fols. 20 v. -21 r. 1414, gener, 16. Pina. 
també en seu metropolitana, les coronacions començaren a ésser presidides pel seu arquebisbe ${ }^{188}$.

Hauria pertocat, en conseqüència, a l'arquebisbe de Saragossa coronar Ferran d'Antequera. Però des que, el juny de 1411, en un dels episodis més foscos de l'Interregne, García Fernández de Heredia havia estat assassinat, el papa Benet XIII retenia el govern de la diòcesi a les seves mans $i$, de fet, la seu romangué vacant fins al $1415^{189}$.

Tot i que la crònica de Pérez de Guzmán digui que Ferran fou ungit, consagrat i coronat per l'arquebisbe de Tarragona i que aquest, fins i tot, en contra del ritual establert, li imposà la corona, degué ésser el bisbe d'Osca qui, en realitat, i tal com no es cansa de repetir la crònica de García de Santa María, actuà com a metropolità̀ ${ }^{190}$.

La documentació reflecteix, en efecte, els problemes que tingueren, per arribar a un acord sobre la presència del bisbe d'Osca a la coronació, el monarca i el papa Luna. La crònica d'Álvar García semblaria, en conseqüència, el testimoni més fiable, ja que l'autor ho presencià i parla constantment del bisbe d'Osca; però, sense deixar clar quina fou la solució, la documentació també apunta cap a altres possibilitats.

El desembre de 1413, el rei havia escrit al papa per suplicar-li que donés llicència al bisbe d'Osca per participar a la cerimònia de la seva coronació, però Benet XIII li havia contestat, per mitjà del bisbe de Barcelona, que no creia que aquell, que estava al seu servei, pogués assistirhi, puix que considerava on que feia més falta era al seu costat. Per això, Ferran tornà a insistir-li perquè consentís que tant l'oscenc com tots els prelats de la Corona fossin amb ell a Saragossa, al-legant que hi hauria diversos nobles i cavallers de nacions estrangeres ${ }^{191}$.

Desconeixem, malauradament, quina fou la resposta de Pero de Luna, però allò més probable és que les gestions reials no tinguessin l'èxit desitjat i que el papa no cedís, almenys abans de la primeria de gener de

${ }^{188}$ B. PAlacios, La coronación, pp. 106-109.

${ }^{189} C f$. E. SARASA, Fernando I, p. 7, nota 1.

${ }^{190}$ I. MaCDONALD, A Coronation Service, p. 362, demostra que tant la menció de l'arquebisbe de Tarragona com a oficiant de la cerimònia com la pretensió que fos ell qui col-loqués la corona al rei són alguns més dels errors de la Crónica del rey don Juan, p. 360. Posteriorment, aquest error ha passat desapercebut $i$ ha estat repetit per alguns autors. El propi E. SARASA, Fernando I, p. 15, i Aragón, p. 84, diu que Ferran fou ungit pel bisbe de Saragossa i coronat per l'arquebisbe de Tarragona.

${ }^{191}$ ACA, C., reg. 2404, f. 9 r. 1413, desembre, 31. Lleida. 
1414. Aleshores, el rei envià Lope Gonzalo d'Olmedo a la cort pontifícia a parlamentar super nonnullis honorem nostrum ac felicem expedicionem nostre prospere concernentibus, però amb ordres del tot diferents:

\begin{abstract}
bien sabedes como havemos ambiado a supplicar a nuestro senyor, el Padre Santo, que plaziesse a Su Santedat acomandar la administración de la església de Çaragoça, por raçón de los actos de nuestra beneventurada coronación, al reverent padre en Christo el archebisbe de Tarragona. E, como la jornada de la dita nuestra coronación sea muyt breve, rogámosvos affectuosament e encaragamos que, de nuestra part, instedes e suppliquedes el dito nuestro senyor el Padre Santo, en virtut de la creencia que vos acomendamos, que plega a la Sua Santedat acomandar la administración de la dita església sobre los ditos actos e tanto como aquellos durarán al dito archebisbe, como sea a major prelado de nuestra senyoría, o al menos al bisbe de Barcelona ${ }^{192}$.
\end{abstract}

Tot el que podem afegir és que, quinze dies després, la discussió encara era oberta; que, aleshores, el papa havia proposat al monarca enviarli, per ungir-lo durant la coronació, el cardenal de Montearagón; i que Ferran, preocupat perquè aquest fet podia ser mal interpretat i crear conflictes, li suplicà que, en tot cas i com a mínim, el revestís de dignitat episcopal, ut inde quolibet ambiguitas hac de causa penitus auferatur ${ }^{193}$.

Abans de la seva coronació, Ferran I també intentà, com és lògic, allunyar de la ciutat de Saragossa tota màcula que pogués deslluir l'esplendor d'aquella festa solemne, qualsevol ombra que pogués relacionar-se amb els esdeveniments de l'Interregne i amb les persistents bandositats. Per això, a la fi de desembre de 1413, també va sol-licitar al papa que, durant les festes de la coronació, alcés l'entredit que pesava sobre la ciutat ${ }^{194}$. Així ho comunicà als jurats i prohoms saragossans, tot exposant-los que ell, tan bon punt arribés a la ciutat, ja s'ocuparia personalment del problema i el solucionaria per la via civil; a més, els donà instruccions clares sobre $\cdot$ l feyto de los foraexidos de Çaragoça, ordenant-los que los ditos foraexidos no permetades seyer o finquar en la dita ciudat porque en l'acte [de] nuestra coronación non se podiesse, por razón d'ellos, alguna occasión scaeçer ${ }^{195}$.

\footnotetext{
${ }^{192}$ ACA, C., reg. 2404, fols. 12 v. - 13 r. 1414, gener, 7. Lleida.

${ }^{193}$ ACA, C., reg. 2404, fol. 90 r. - v. 1414, gener, 22. Saragossa.

${ }^{194} \mathrm{ACA}, \mathrm{C}$, , reg. 2385 , fols. 1 v. - 2 r. 1413, desembre, 28. Lleida.

${ }^{195}$ ACA, C., reg. 2404 , fol. 7 v. 1413 , desembre, 27. Lleida.
} 


\section{El CONVIT}

Després de l'acte litúrgic de la coronació i del retorn cap al palau de l'Aljafería en comitiva, el monarca coronat hi havia d'oferir un convit o banquet de celebració.

Per col-locar i distribuir els convidats, calia també, evidentment, seguir un protocol. Tot just a la primeria de desembre, el rei ja se'n preocupà: li calia conèixer la nòmina dels prelats, nobles e universitats insignes e la manera com deuen seure e ésser col locats a la festa de convit, per tal de poder-hi proveir amb temps i adequadament ${ }^{196}$.

Per a tovalles de la festa, el rei va encarregar mil canes de llenç de Xampanya i cinc-centes canes de lens bordat del ampla per los dressadors e a les taules de la gent comuna ${ }^{197}$.

D'entre els aliments i productes que es consumiren, el vi, els sucres i confits, la volateria i la fruita són els que ens han deixat més traces.

Al marge del banquet, el ritual preveia que també durant la cerimònia religiosa es consumissin vi i confits. Segons l'Ordinació de Pere el Cerimoniós, la vigília de la coronació al vespre, després d'haver arribat a la Seu de Saragossa en comitiva i d'haver dit una oració, el rei havia d'asseure's al seu setial de drap d'or i se li havien de servir confits i vi, que ell havia de fer repartir entre tots els presents ${ }^{198}$. I així ho féu Ferran d'Antequera el dia 10 de febrer, segons relació d'Álvar García ${ }^{199}$. L'endemà, el vespre del dia de la coronació, durant el ball posterior al banquet, el rei va demanar $\mathrm{i}$ oferir de nou espècies $\mathrm{i} \mathrm{vi}^{200}$.

L'Ordinació, en canvi, no preveia com havia de ser el convit, sinó només la disposició de les taules i la decoració i ambientació de la sala. I, malauradament, les cròniques no són pas gaire esplèndides en parlar dels aliments que se serviren, ja que se centren sobretot en el muntatge $i$ espectacle que envoltava cada plat. Álvar García només ens permet saber que a esta sala fueron traidos, a las dichas tablas, muchas viandas e manjares

\footnotetext{
${ }^{196}$ ACA, C., reg. 2403, fol. 151 r. 1413, desembre, 5. Lleida.

${ }^{197}$ ACA, C., reg. 2383, fol. 171 r. [1413, novembre, 13. Lleida].

${ }^{198}$ Ordinació, p. 273.

${ }^{199}$ D. FERro, Le parti inedite, p. 101.

${ }^{200}$ Ibídem, p. 120.
} 
de pavones, e capones, e gallinas, e diversos potajes; que muy solemnemente entró el primer manjar por la puerta de la sala, e venian en los taxadores pavones con sus colas alçadas cubiertos los cuerpos dellos con fojas de oro e sus armas de Aragón, e tenían sus cuellos altos con la su devisa del estola; i que, posteriorment, entre representació i representació, entró el mayordomo con el segundo manjar, los platos e tajadores llenos de muchos capones $e$ pasteles dorados e pasteles de diversas aves vivas e otros muchos manjares. Quan s'obriren els pastissos, van sortir-ne aus volant ${ }^{201}$.

El novembre de 1413, el rei ja havia encarregat, per a la seva coronació, sis bótes de vi grec del millor i més fi que es pogués trobar de Nàpols, i havia reservat dues bótes de malvasia vingudes de Sicília que el tresorer reial tenia a casa seva ${ }^{202}$. Les bótes de vi i de malvasia, i altres coses que no podien anar a peu de bèstia, havien de ser enviades des de Barcelona fins a Tortosa per $\operatorname{mar}^{203}$. El rei demanà que, un cop a Tortosa, el vi fos dut a Saragossa per la via més ràpida, fos per terra o pel riu. Però, malgrat les precaucions, durant el viatge fins a Tortosa una part del vi es va malmetre ${ }^{204}$.

El sucre utilitzat durant les festes també procedia de Sicília; el mercader Guillem de Fonollet n'importà, amb aquesta finalitat, almenys sis càrregues $^{205}$. Al revés que el vi, els sucres foren tramesos a Saragossa per terra, ab bones azembles, en tal manera que no's pusquen guastar ${ }^{206}$. La part del sucre destinada a la fabricació de confits havia de ser lliurada a l'especier reial, Guillem Casanyes, que, a l'inici de desembre, ja es dirigia a Saragossa per començar-los a preparar; per això, el rei ordenà a l'escrivà de ració que, tota dilación a part posada, dedes e liuredes al dito speciero nuestro todo aquell çucre que pora confección de los ditos confites

${ }^{201}$ Ibidem, pp. 113, 114 i 118.

${ }^{202}$ ACA, C., reg. 2383, fol. 171 r. [1413, novembre, 13. Lleida].

${ }^{203}$ ACA, C., reg. 2383 , fols. 171 v. - 172 r. 1413, novembre, 14. Lleida.

204 " $E$, noresmenys, lo vi que vench de Barcelona que no sia consumat o affollat nos enviats per terra o per lo riu, per llà on abans sia açí"; ACA, C., reg. 2404, fol. 90 v. 1414, gener, 20. Saragossa.

${ }^{205}$ ACA, C., reg. 2383 , fol. 171 r i 171 v. (1413, novembre, 13 i 14. Lleida; 2 documents) i reg. 2428 , fol. 35 r. - v. (1414, maig, 24. Saragossa). Sobre Guillem de Fonollet, vegeu la nota 122 .

${ }^{206}$ ACA, C., reg. 2403 , fol. 146 v. 1413, novembre, 27. Lleida. 
necessario haurá, por tal qu'él pueda haver tiempo de obrar aquellos ${ }^{207}$. Per tal que l'especier pogués començar-hi a fer els confits, al palau de l'Aljafería calia ter-hi obres i adobs ${ }^{208}$. Però alguns dels traginers que es dirigien a Saragossa amb els muls carregats amb les caixes i els costals de medecines de l'especier van descarregar i deixar abandonades les càrregues a la vila de Fraga; amb gran indignació, el monarca ordenà que els responsables fossin cercats, presos $\mathrm{i}$ enviats a ell perquè els pogués castigar $^{209}$.

Per raó dels confits, sucre i altres especieries que Guillem Casanyes hagué de comprar per al rei (encara que no tots, necessàriament, destinats a les festes de la coronació), la cort li va quedar a deure, com a mínim, 1392 florins i mig ${ }^{210}$.

Entre la que fa referència al convit reial, la informació sobre la recerca, transport i manteniment de la volateria per a les festes de la coronació és de la més interessant. Com deia Álvar García, se serviren muchas viandas e manjares de pavones e capones e gallinas ${ }^{211}$.

A l'inici de desembre, el rei ja disposà que s'enviessin a Saragossa els pagos o paons necessaris per a les festes, per tal que hi hagués temps suficient per engreixar-los ${ }^{212}$. Una bona part dels paons foren tramesos a Saragossa des de València juntament amb moltes de les coses destinades a les festes de les que es féu càrrec el batlle general del regne, Joan Mercader. Buscar i comprar els seixanta-set paons, entre mascles i femelles, que forniren les terres valencianes no va ser fàcil. A un porter reial li calgueren quinze dies per localitzar-ne trenta-nou al comtat de Dènia, i un altre tardà nou dies per trobar-ne sis a Càrcer i a la Pobla d'Artiaga. Els vint-i-dos restants foren comprats a la mateixa ciutat de València. Els paons foren traslladats, primer, a València, en cabassos de palla d'ordi i en sàrries. Posteriorment, Mahomat Benamir, sarraí de Benagutzir, els portà, amb tota

\footnotetext{
${ }^{207} \mathrm{ACA}$, C., reg. 2399, fol. 91 r. - v. 1413, desembre, 12. Lleida.

${ }^{208}$ ACA, C., reg. 2403 , fols. 157 v. -158 r. [1413, desembre, 15. Lleida].

${ }^{209} \mathrm{ACA}, \mathrm{C}$, reg. 2404 , fol. 89 r. 1414, gener, 12. Campdàsens.

${ }^{210} \mathrm{ACA}, \mathrm{C}$, reg. 2412, fol. 122 r. 1415, juliol, 13. València.

${ }^{21}$ 'D. FERRO, Le parti inedite, p. 101.
}

${ }^{212}$ ACA, C., reg. 2403, fol. 151 r. 1413 , desembre, 5. Lleida. Pocs dies després, quan a Saragossa ja hi començava a haver moviment, l'escrivà de ració demanà al rei que li enviés dos porters i el museu, el funcionari reial encarregat de guardar i administrar els comestibles, que li devia ser necessari per disposar-ho tot convenientment; ACA, C., reg. 2403, fols. 157 v. 158 r. [1413, desembre, 15. Lleida]. 
cura, cap a Saragossa, en tres viatges, i amb l'ajut, durant el camí, d'un altre home. Durant el viatge, els paons foren alimentats amb daça i pa, comprat expressament per a llur provisió ${ }^{213}$.

El convit obligà també a intentar aconseguir tantes perdius com fos possible, que foren caçades en localitats aragoneses properes. El rei va mobilitzar, amb aquesta finalitat, les universitats, prohoms i procuradors d'Escatron, Casp, Alcanyís, Montalban, Terol, Daroca, Calataiud, Tarazona, Ejea i Uncastillo, tot prometent-los que, per cada parell de perdius que cacessin, rebrien 2 sous i 6 diners ${ }^{214}$.

Pel que fa als capons i a les gallines, s'obtingueren, també. a diversos llocs d'Aragó, o si més no als que formaven part del comtat d'Urgell. Se n'havia donat càrrec a Diego, bisbe de Zamora, el comissari i receptor dels diners procedents de les demandes de la coronació en aquell regne, que envià un comissari als llocs del comtat d'Urgell que eren a Aragó per saber i taxar els parells de gallines i de capons que podia procurar cadascun 215 .

Entre les coses que, de bon principi, juntament amb el vi grec, la malvasia i el sucre, el rei ja havia sol-licitat que li fossin enviades de Barcelona a Saragossa, hi havia també gingebre verd, pomes de Domas, confits i salsos fines ${ }^{216}$.

Però les espècies i la fruita fresca, com era habitual ${ }^{217}$, procediren, sobretot, de València, gràcies a adquisicions fetes pel batlle general. Per als àpats de la coronació, n'arribaren poncirs, taronges, llimons i llimes en canastes de canyes lligades amb tronyelles i, a València, igualment, també

${ }^{213} \mathrm{ACA}, \mathrm{C}$, reg. 2412 , fols. 103 r. - 109 v. 1415 , abril, 24. València.

214"Hombres buenos: como por la fiesta e solemnidat de nuestra benaventurada coronación hajamos neçessarias haver perdizes, vos mandamos, assí streytament como podemos, que, vistas las presentes, caçades e fagades caçar, assí de día como de nueyt; e la dita caça enviat aquí al fiel scrivano de ración nuestro en Nicholau de Biota, el qual pagará a aquellos qui las ditas perdizes adurán el par a II s. VI d."; ACA, C., reg. 2404, fol. 25 r. 1414, gener, 27. Saragossa.

215 "hun comissario que 1 dicho vispo huvo de enviar a los lugares del condado d'Urgell que son en Aragón, con comisión del dicho vispo, por saber quántos pares de gallinas e capones poría haver de los dichos lugares pora la fiesta de nuestra coronación e repartir aquellas por los dichos lugares"; ACA, C., reg. 2413, fols. 63 r. - 66 r. 1414, maig, 7. Saragossa.

${ }^{216}$ ACA, C., reg. 2383, fol. 171 r. [1413, novembre, 13. Lleida].

${ }^{217} \mathrm{M}$. TinTó, Cartas del baile, pp. 45-49, recull diversos documents que reflecteixen les constants trameses de fruita fresca valenciana a Ferran d'Antequera. Aquesta mena de notícies són molt abundants entre la documentació de Cancelleria del regnat de Ferran 1. 
s'hi compraren ametllons, fideus i arròs. Per collir els cítrics, almenys vuit càrregues, destinats especialment a l'ocasió, van fer falta cinc homes ${ }^{218}$. La majoria de compres es van fer a mercaders sarraïns i els transportistes, sovint, també ho foren.

\section{ELS ENTREMESOS}

La crònica d'Álvar García de Santa María descriu amb molt detall les actuacions i espectacles que es feren durant les festes de la coronació, especialment les que acompanyaren el banquet ${ }^{219}$. Però, mentre la comitiva tornava cap a l'Aljafería, després de la coronació, els carrers de Saragossa també eren plens de gent i d'espectacle. Durant el trajecte, el monarca es trobà, essencialment, amb dues construccions al-legòriques, l'una que feia referència a la presa de Balaguer i a la derrota de Jaume d'Urgell ${ }^{220} \mathrm{i}$ l'altra a l'elecció de Ferran, a Casp, entre els altres pretendents al tron ${ }^{221}$.

Abans d'arribar a palau, el rei va trobar també els jueus de la ciutat que, enfilats dalt d'una bastida, cantaven al seu pas, a grans veus, com era costum, els càntics de la Torà 222 .

Com ja hem dit, cada plat o menjar que se serví durant el convit anava acompanyat de sus juegos. Si resseguim la descripció que en fa García de Santa María, hi podrem reconèixer, després, la majoria d'entremesos i d'elements teatrals que, durant els preparatius de la celebració, el monarca s'ocupà d'aconseguir .

Sobre la porta d'entrada a la sala hi havia tres rodes, que tenien, a banda i banda, vuit grades, i que representaven els cels. Tot el muntatge era

\footnotetext{
${ }^{218}$ ACA, C., reg. 2412, fols. 103 r. - 109 v. 1415, abril, 24. València.

${ }^{219}$ Sobre el paper que hi tingueren la Verge i l'Orde de la Gerra i el Grifó, vegeu A. MACKAY, Don Fernando de Antequera y la Virgen Santa Maria, dins Homenaje al profesor Juan Torres Fontes, vol. II, Múrcia, 1987, pp. 949-956.

${ }^{220}$ D. FERRO, Le parti inedite, p. 110.

${ }^{221}$ Ibídem, pp. 110-111.

${ }^{222}$ Ibídem, p. 111. F. VENDRELL, La presencia de la comunidad judía, dedica unes pàgines a analitzar la participaçió jueva a les festes de la coronació de Ferran d'Antequera a partir d'aquesta referència d'Álvar García. Desconeix, però, una altra menció de la crònica a aquesta minoria: "los judíos vestidos como christianos dançando e bailando con cintas de plata ceñidos, e sus juglares delante dellos, e ansí todos los días de la dicha fiesta, vinieron por las calles faciendo sus alegrías fasta entrar en los palacios del dicho señor rey" per fer-li reverència, Coronaciones, $c f$. M. TinTó, Cartas del baile, p. 309.
} 
de "color del cel". Sobre una de les rodes hi havia un cielo más alto que los otros, en el qual estaban dos niños muy bien guarnidos de paños de oro, $e$ estaba el uno al otro poniendo una corona en la cabeça, a remembrança de quando Dios coronó Sancta María, però també, sens dubte, simbolitzant la coronació de Ferran. Les tres rodes, que giraven, estaban llenas de hombres vestidos de paños blancos e con alas grandes doradas e con rostros sobrepuestos a paresciencia de ángeles, e tan fermosos que bien parescian ángeles ${ }^{223}$.

Sobre les grades, en canvi, hi havia asseguts prínceps, profetes $\mathrm{i}$ apòstols, cada uno su señal en la mano por do era conocido. A la primera grada hi havia set homes en semejanças de los siete pecados mortales, $e$ deyuso dellos en las tablas a sus pies estaban pintadas siete cabeças de demonios en semejança de los siete pecados mortales; e en la segunda grada estaban siete moços con rostros e sobrepuestos que parecian diablos que atormentaban a los siete pecados mortales. A la tercera grada hi havia les set virtuts, i a la quarta els set àngels corresponents ${ }^{224}$.

Mentre menjaven el primer plat,

Dios padre movió todos los cielos e dende partió una gran nube e decendió delante de la mesa en igual de los paños franceses que estaban puestos en la sala alto del suelo con una lança de armas e salió de la nube un ángel cantando, trayendo en la mano una espada desnuda de la vaina e dixo dos coplas ansí en limosín.

Després de recitar, el núvol va pujar l'àngel fins als cels, i els del paradís tocaren llurs instruments ${ }^{225}$.

Tot seguit, s'anaren alçant els pecats mortals, amb llurs corresponents diables, per recitar, cadascun, dues coples. Tot just havien acabat, se'ls aixecaren en contra les set virtuts contràries, que també cantaren coples ajudades pels seus set àngels ${ }^{226}$.

Quan Diligència i el seu àngel hagueren acabat,

\footnotetext{
${ }^{223} \mathrm{D}$. FERRO, Le parti inedite, pp. 113-114.

${ }^{224}$ Ibidem, pp. 114-115.

${ }^{225}$ Ibídem, p. 115.

${ }^{226}$ Ibídem, pp. 115-118.
} 
se revolvieron los cielos, e en medio de la sala salió una nube en la qual venía la Muerte, la qual era muy fea, llena de calaveras e culebras e galápagos, e venía en esta guisa. Un hombre vestído en baldreses amarillos justos al cuerpo que parecía su cuero, e su cabeça era una calavera e un cuero de baldres toda descarnada sin narizes e sin ojos, que era muy fea e muy espantosa, e con la mano faziendo semejanças a todas partes que llevaba a unos e a otros por la sala.

Posteriorment, el núvol se la tornà a endur cap als cels, i aleshores entrà el majordom amb el segon plat ${ }^{227}$.

Durant el convit posterior a la coronació de la reina es repetiren els mateixos entremesos, però el número de la Mort tingué algunes variacions. Quan la Mort davallà, mossèn Borra, un albardán que tenía el rey de Aragón muy gracioso que non dezía mal de ninguno, salvo que tenía gracias que le daban todos (...) pero era home bien pequeño de cuerpo e buen gramático, que era a la sala on menjava la reina, va mostrar grande espanto en la ver a la Mort e daba grandes vozes a la Muerte que no viniesse. D'acord amb el rei, quan la Mort sortí del núvol davant de la taula de mossèn Borra, que cridava com un desesperat, el duc de Gandia l'hi va lliurar, la Mort tregué una soga e atáronla al cuerpo al dicho Borra, e la Muerte lo guindó arriba, e aqui veríades las maravillas de las cosas que mossén Borra fazía, e del llorar e del gran miedo que le tomaba ${ }^{228}$.

En entrar el primer plat, davant dels qui duien les safates, havia sortit un muy fermoso grifo, todo dorado, tan grande como un rocín, e traía una corona de oro al pescueço, e iba todavía echando fuego ${ }^{229}$. L'entrada del segon plat també anà precedida de l'aparició del dicho grifo echando fuego por la sala, faziendo lugar por do passassen los que llevaban los manjares. Però ara,

en pos del grifo, delante del manjar, iba una grande roca como manera de castillo de madera pintado sobre sus carretones, e en medio del dicho castillo iba una jarra de Sancta María con sus lirios blancos de plata bruñida muy grande. En el dicho castillo iban seis donzellas cantando cantos muy dulzes de oir, e en el canto del dicho castillo iba una águila dorada muy

\section{${ }^{227}$ Ibídem, p. 118.}

${ }^{228}$ Tan gran era la por que tenia mossèn Borra que, en subiendo, fizo sus aguas en sus paños, que corrió en las cabeças de los que deyuso eran, que bien tenían que lo llevaban al Infierno; ibídem, pp. 126-127.

${ }^{229} \mathrm{Ibidem}$, p. 113. 
grande coronada, traía en el cuello un collar de la devisa de las jarras del rey de Aragón, e la jarra que era en medio del castillo andaba a la redonda quando la movían ${ }^{230}$.

Molts d'aquests elements els podem localitzar perfectament entre les notícies que fan referència als preparatius de les festes $i$, fins i tot, podem saber d'on procedien.

A la darreria de novembre de 1413, per exemple, Ferran comunicà a Nicolau de Biota que havia escrit a Barcelona per algunes coses necessàries per als entremesos de la coronación ${ }^{231}$. En realitat, ho féu al cap d'uns dies, demanant als consellers i prohoms de Barcelona que,

per nostra complacència e servir, nos emprestets los tres entremesos, çò és, lo drach e l'àliga e lo basaliç ab totes les coses a aquells necessàries perquè servesquen a la festa de la nostra benaventurada coronación ${ }^{232}$.

L'àliga del castell, per tant, era de Barcelona, i el grifó, meitat àliga i meitat lleó, potser pot assimilar-se amb algun dels altres dos entremesos barcelonins, que a la festa podrien haver aparegut caracteritzats diversament.

El propi rei volgué encarregar-se de dissenyar i de supervisar els entremesos que volia per la festa. Per això envià, en un memorial, les seves idees a l'escrivà de ració i a Antonet Sanç, de la seva capella, que n'eren els responsables a Saragossa ${ }^{233}$. Malauradament, potser perquè per desig exprés del monarca tot havia de preparar-se en secret, als registres de cancelleria no hi ha cap còpia d'aquest memorial, però la carta del rei que l'acompanyava permet entreveure algunes de les seves suggerències:

Scriván de ración e Anthonet: como nós hajamos de[lib]erado que por a la fiesta de nuestra bienaventura $<\mathrm{da}>$ coronación se fagan los entremesos contenidos en un memorial que vos enviamos con la present, mandámosvos

${ }^{230}$ Ibidem, pp. 118-119.

${ }^{231}$ ACA, C., reg. 2383, fol. 180 v. 1413, novembre, 25. Lleida.

${ }^{232}$ ACA, C., reg. 2403, fol. 149 r. 1413, desembre, 2. Lleida; citat per M. TINTÓ, Cartas del baile, p. 69, nota 80 .

${ }^{233}$ Antonet, el capellà del rei, fou l'encarregat de la realització dels entremesos: "Anthonet: ja per altra letra vos havem scrit que vinguéssets a nós, que us havem mester per fer entremesos e altres coses necessàries a la solempnitat de la festa de la nostra coronació, perquè us pregam e manam que, si ja partit no sóts, partiscats de continent per anar a Çaragoça a fer los dits entramesos"; ACA, C., reg. 2403, fol. 151 r. 1413, desembre, 5. Lleida. 
que aquellos fagades secretament segund la forma contenida en el dito memorial e que alguno no lo sepa fasta que sea fetxo la jornada de nuestra coronació. Del entramés que devíades fazer del teyado, nuestra merced es que no lo fagades ne curedes d'ell (...). Del feyto del entramés de la mort e de set testes de diables muyt feres, nós havemos scripto als conselleros de Barcelona qui les nos enprestarán ${ }^{234}$.

El rei va saber imposar, en tot moment, la seva voluntat, sovint oposada a la dels seus servidors. A mitjan desembre, per exemple, rebutjà una de les propostes per als entremesos que li havia fet Nicolau de Biota, ja que considerava que no fóra cosa digna:

En çò que ns feu saber que havíeu per acordat fer entremès que la Verge Maria fos devant nós ab certs altres entremeses e que un àngel devellàs d'alt per servir a nós, a nós no plau ne volem que tal entremès se faça, com no seria digna cosa; més, en loch d'aquex, feu-ne d'altres que sien bons e plasents $^{235}$.

La carta a Barcelona, anunciada a la primeria de desembre, per demanar els set caps de diables que durant la festa acompanyaren els set pecats capitals i l'entremès de la mort que ja hem vist en acció a la crònica d'Álvar García, és, però, bastant més tardana, de gairebé un mes després. Els consellers barcelonins havien de lliurar el material a Lleonard de Sos, que el trametria al rei i que, posteriorment, els el retornaria un cop passada la festa:

Pròmens: com nós hajam a cor que la festa de nostra beneventurada coronació si<a $>$ feta ab aquella major solemnitat que fer se pusca, pregam-vos affectuosament que, per la dita festa, nos vullats prestar set figures de diables, les <pus> pròpies e les pus feres que tingats, e axí metex l'entremès o joch de la mort que fes fer quant nós entram en aquexa ciutat, e aquellas vullats liurar al feel loctinent de maestre racional de la nostra cort, en Leonard de Sos, per tal que los trameta de continent a Çaragoça, car nós li scrivim que $s \cdot i$ obligue a vosaltres que acabada e finida la dita festa de la nostra coronació, la qual no durarà sinó VIII jorns, ell

${ }^{234}$ ACA, C., reg. 2404 , fol. 85 v. 1413 , desembre, 4. Lleida.

${ }^{235}$ ACA, C., reg. 2403 , fols. 157 v. - 158 r. [1413, desembre, 15. Lleida]; citat per M. TinTó, Cartas del baile, p. 69. 
vos restituirà les dites VII figures de diables e l'entremès o joch de la mort dessús dits ${ }^{236}$.

Els barcelonins facilitaren al monarca, per tant, els entremesos i les figures més funestes de la festa.

En canvi, les set figures d'àngels i els arcàngels que ocuparen el sector celestial de la graderia que presidia l'espectacle, que davallaren dels cels i que acompanyaren les virtuts, procediren de València. Fou un cop més Joan Mercader qui rebé l'encàrrec de sol-licitar-les:

com nós, per decorar e ennoblir la festa de nostra beneventurada coronació, vullam haver les testeres, ales, camís e altres apparellaments dels àngells qui sonen davant la custòdia, e axi matex dels àngels sant Gabriel e sant Miquel, les quals servexen cascun any a la festa de Corpore Christi e són en poder dels jurats de aquexa ciutat, pregam-vos e manam que, de nostra part, los digats, en virtut de la creença que us acomenam, pregant-los afectuosament, que les dites testeres, ales, camís e altres apparellaments nos presten, los quals los prometets per nós restituir e tornar aquí solemnitzada la dita festa, fahent-los de açò aquella seguratat que volran ${ }^{237}$.

Les cares i ales dels àngels devien ser-ne la part més delicada; per això viatjaren en caixes especials, lligades amb cordes, que foren trameses a Saragossa juntament amb el material dels batifullers en sis bèsties de càrrega comanades per Mahomat Adzelori. De retorn cap a València, els diversos elements dels àngels viatjaren en tres atzembles conduïdes per Mahomat Benamir, de Benagutzir ${ }^{238}$.

${ }^{236}$ ACA, C., reg. 2404 , fol. 84 r. 1414 , gener, 1. Lleida; carta explicativa adreçada a Lleonard de Sos, de la mateixa data, fols. $83 \mathrm{v}$. - $84 \mathrm{r}$.

${ }^{237}$ ACA, C., reg. 2403, fol. 153 r. 1413, desembre, 9. Lleida; citat per M. TinTó, Cartas del baile, p. 69, nota 81 . La creença adreçada als jurats i prohoms de València en favor de Joan Mercader és de la mateixa data $i$ té la mateixa referència. Hi ha també una altra carta semblant dirigida a Lleonard de Sos perquè doni als prohoms valencians la seguretat que vulguin i els prometi restituir-los tot el material un cop solemnitzada la festa a ACA, C., reg. 2383, fol. 186 r. - v. 1413, desembre, 9. Lleida.

${ }^{238}$ ACA, C., reg. 2412 , fols. 103 r. - 109 v. 1415 , abril, 24. València. 
Bernat i Bartomeu de Santalívia ${ }^{239}$, Aleix Moragues, mestre de bastides ${ }^{240}$, Anton Ruiz, criat de Joan Gutierro i també mestre de bastides $^{241}$, i, com ja havíem dit, Antoni Sanç, capellà de la capella reial ${ }^{242}$, foren els encarregats de construir i fer els entremesos.

\section{ELS JOGLARS}

Al llarg de la crònica de García de Santa María trobem, constantment, mencions de joglars que toquen llurs instruments, que canten i que ballen, però no hi trobem cap descripció més concreta ni precisa. En canvi, les fonts documentals reflecteixen un viu interès de Ferran d'Antequera per disposar d'un grup concret de joglars, procedents del regne de València, los jutglars moros alfuleys ${ }^{243}$ que $a b$ ses mullers (...) acustumaven servir al senyor rey en Marti ${ }^{244}$.

239" En Bernat hi Barthomeu Sentalívia: com nós hajam deliberat fer alguns entremesos per decorar la festa de nostra beneventurada coronació e en la spedició de aquells vosaltres sots mester, vos manam e pregam que, vista la present, vingats a la ciutat de Çaragoça"; el mateix dia Ferran comunicà a Nicolau de Biota que els admetés al seu servei, ja que els enviava a Saragossa "per obrar els preparatoris necessaris" per la seva coronació; ACA, C., reg. 2403, fol. 166 r. 1413, desembre, 20. Lleida.

${ }^{240}$ El 26 de març de 1414 Ferran ordenà a Ferran de la Cavalleria que pagués a Aleix Moragues, mestre de les seves bastides, 100 florins d'or d'Aragó que li oferia graciosament en esmena dels treballs que havia sostingut "per fer los castells e altres entramesos qui serviren a la solemnitat de les festes de la nostra benaventurada coronació" i 14 florins més perquè es comprés drap de sestra per fer-se una cota; ACA, C., reg. 2413, fol. $40 \mathrm{v}$.

${ }^{241}$ ACA, C., reg. 2413, fol. 69 r. 1414, abril, 30. Saragossa.

${ }^{242}$ El 26 de març Ferran ordenà al seu tresorer, Ferran de la Cavalleria, que li pagués 100 florins d'or d'Aragó que volia donar-li en esmena i satisfacció dels treballs "en fer los entramesos e altres obres en la solemnitat de nostra benaventurada coronació"; 25 florins perquè es comprés drap de mustmaler; i 666 sous 8 diners jaquesos per comprar mil panxes de vays blancs per una folradura; ACA, C., reg. 2413, fol. $40 \mathrm{r}$.

${ }^{243}$ La documentació qualifica o denomina constantment alfuleys aquests joglars sarraïns, però només podem intuir-ne el significat a partir del context. No sembla pas que es tractés d'una mena específica de músic o d'instrument (M.C. GómEZ MUNTANTÉ, La música en la casa real catalano-aragonesa. 1336-1432, Barcelona, 1979, no esmenta cap denominació semblant). M. TinTó, Cartas del baile, p. 69, notes 77, 78 i 79, i p. 319, que menciona algun dels documents en què apareixen, tampoc no en pot precisar el significat; i F. VENDRELL, Presencia de la comunidad judia, p. 382, identifica els alfoleis amb moros balladors, però només a partir del context.

${ }^{244} \mathrm{ACA}, \mathrm{C}$., reg. 2403 , fols. 166 v. -167 r. 1413, desembre, 22. Lleida. Ferran demanà al batlle general del regne de València que, immediatament, els fes vestir tots d'un mateix color i els enviés a Saragossa, on haurien de ser abans del 12 de gener. 
Els juglars alfuleys que el batlle general de València, a sol licitud del rei, va enviar, vestits d'un sol color, a Saragossa, eren sis moros i tres mores. Per vestir-los, calgueren dues peces de drap verd verví de la terra, una de drap blanc i una de vermell. A part, es compraren dotze alnes de fres per les joglaresses mores alfuleies i un guarniment de drap de lliurea per als alfuleis. Llurs cotes foren folrades amb tela d'espinal verd i llurs banastells foren enviats a Saragossa en dos caixons ${ }^{245}$. Procedien de Xàtiva, Eslida, Mislata i Gandia. Es trobaren tots a València, on hagueren d'esperar que els fossin fetes les robes i, després, feren camí, plegats, cap a Saragossa, on romangueren dotze dies. Dos d'ells, com a mínim, hi arribaren cavalcant bèsties de sella ${ }^{246}$. Els que eren de Xàtiva iniciaren el camí de retorn, un cop acabades les festes, el 22 de febrer, després d'haver estat degudament gratificats pel monarca ${ }^{247}$.

Com ja hem dit en parlar dels assistents i convidats a la coronació, és possible que els catorze moros de Medellín -una de les possessions castellanes de Ferran d'Antequera- que hi assistiren fossin també joglars ${ }^{248}$.

\section{LES JUSTES I TORNEIGS}

En parlar dels preparatius de robes i vestidures ja hem pogut veure que, d'acord amb allò que diuen els cronistes, Ferran d'Antequera organitzà un torneig de cent contra cent i posà quinze taules de junyir al Campo del Toro.

\footnotetext{
${ }^{245}$ ACA, C., reg. 2412 , fols. 130 r. - 109 v. 1415, abril, 24. València.

${ }^{246}$ Ibidem.

${ }^{247}$ Segons la carta que Ferran envià al seu tresorer, Ferran de la Cavalleria, perquè els satisfés les despeses que havien tingut, llur cap o responsable devia ser Affi Ali Affullay Mari, a qui havia de pagar, "per sí e per los altres moros e mores juglars qui, per rahó de la solemnidat de nostra beneventurada coronació, són venguts açi a nós, sexanta-cinch florins d'or d'Aragó, los quals és nostra mercè donar-los per paga e les posades en què han stat e posat açí com per loguers de adzembles e altres messions e despeses que necessàriament los convendrà fer per lo camí tornant-se a Xàtiva en lurs casas"; ACA, C., reg. 2413, fol. 18 v. 1414, febrer, 22. Saragossa. La carta es troba repetida, per error i sense manament, al foli $25 \mathrm{r}$.

${ }^{248}$ Vegeu la nota i el text corresponent a la nota 99 . Podem afegir, a més, encara que no en tinguem cap referència relacionada amb la seva participació als actes de la coronació, que Ferran d'Antequera tenia també, almenys, una joglaressa pròpia, anomenada Graciosa. El 4 de març de 1414 Ferran ordenava al tresorer reial que "donets e paguets a Graciosa, nostra jutglaresa, o a qui ella volrà, vint florins d'or d'Aragó que és nostra mercè donar-li graciosament"; ACA, C., reg. 2413, fol. 24 v.
} 
Per entretenir i distreure els assistents, les justes i torneigs foren els actes que començaren abans i que acabaren més tard. Però com que la seva organització, segons conten les Coronaciones en base al que deu dir García de Santa María, depengué, essencialment, excepte en els dos casos esmentats, de la ciutat aragonesa, no n'hem trobat constància a les fonts reials.

Fou, doncs, la ciudat de Çaragoça, la que

fizo poner dos tablas para justar, una en la plaza, a la puerta que dizen de Toledo, e la otra a la Aljafería, e el rey fizo poner otra de paño vermejo, e amarillo; e ha de costumbre en tales coronaciones la ciudad de Çaragoça poner sus mantenedores, e pusieron por mantenedor a don Joan de Luna, e él se fue a la tabla de la Aljafería, e con él otros tres, que eran quatro justadores, e aí justaron estos con otros cavalleros de los que avían venido a la fiesta, e otros con otros, en manera que todos los días, que fueron de fiestas los más dellos justaron muy bien a maravilla ${ }^{249}$.

Durant els dies previs a la coronació, tant els infants d'Aragó com, amb ells, molts cavallers i escuders catalans, castellans i aragonesos, i fins $i$ tot els ambaixadors granadins, justaren i jugaren a les canyes davant de l'Alfajería. La vigília i el dia de la coronació els torneigs cessaren, perquè tota l'atenció quedà centrada a l'entorn de la cerimònia, de les comitives d'anada i de retorn cap a l'Aljafería i del convit i dels balls posteriors ${ }^{250}$. L'endemà, dilluns, el rei anà a missa i tornà a menjar a la mateixa sala que el dia abans. Les justes es van reprendre havent dinat $i$ fins ben entrada la nit:

e después de comer, a la tarde, don Juan de Luna mantenía la tabla, e vinieron muchos aventureros a justar, (...)e assí fizieron su justa fasta que la oscuridad de la noche tiró su vista e lumbre ante los ojos de los caballe$\operatorname{ros}^{251}$.

Però el gran torneig, el que va organitzar el rei, tingué lloc el divendres dia 16, tres dies després de la coronació de la reina Elionor, al Campo del Toro. Els detalls que en conta García de Santa María

\footnotetext{
${ }^{249}$ Coronaciones, cf. M. TinTó, Cartas del baile, pp. 308-309.

${ }^{250} \mathrm{D}$. FERRO, Le parti inedite, p. 120.

${ }^{251}$ Ibidem, p. 121.
} 
coincideixen perfectament amb allò que en diu la documentació, de manera que aquest és un argument més per prendre en consideració la versemblança de la seva crònica. Segons Álvar García,

\begin{abstract}
el rey abía ordenado, por esta sazón para esta su coronación, torneasen por ciento, e mandó fazer dozientos arneses de torneo con sus viseras e sobrevistas de cendal e espadas guarnidas de torneo, con sus coberturas e sobrevistas de cendal las ciento verdes e las otras ciento vermejas e prietas, e por dar honra a la reina su muger mandó que se fiziesse a la su coronación della ${ }^{252}$.
\end{abstract}

En efecte, a més dels paraments de tornejar, fets la meitat a València i l'altra meitat a Saragossa, que el rei hauria volgut verds i vermells però que, per manca de draps vermells i de temps, alguns havien hagut de ser més foscos ${ }^{253}$, el rei també s'havia ocupat de fer la resta de complements dels tornejadors. Així, a principis de gener, havia ordenat a Nicolau de Biota que fagades fazer, en la manera que se pertanesce e.s deve fazer, CC manyosts e CC spases per los tornajadores que, segunt sabedes, nós havemos ordonado tornejen en la festa de nuestra beneventurada coronacióo ${ }^{254}$.

Després de les festes, el rei es quedà amb els paraments que havia fet fer, o almenys ordenà al seu secretari que lliurés al sots-armer tots els que tingués ${ }^{255}$.

Només coneixem, a partir de la documentació, tres dels cavallers i nobles que foren convidats a prendre part al torneig de cent per cent. Es tracta de Pere de Centelles, Jaume de Centelles i Guillem de Muntanyans que, a mitjan desembre de 1413, ja foren advertits de la voluntat reial que hi participessin i de com s'hi havien de presentar:

segons creem no ignorets, nós havem donada jornada a rebre les insígnies de nostra benaventurada coronació en la ciutat de Çaragoça (...) e, com

${ }^{252}$ Ibidem, p. 127.

${ }^{253}$ Vegeu-ho a l'apartat 10, "Les robes: vestidures i paraments".

${ }^{254} \mathrm{ACA}, \mathrm{C}$, , reg. 2404 , fols. 15 v. -16 r. 1414 , gener, 6. Lleida.

${ }^{255}$ Ferran ordenà al seu secretari, Joan de Tudela, que lliurés tots els paraments que tingués en poder seu (els dos-cents del torneig que havia fet fer a la festa de la coronació, cent dels quals foren verds $i$ cent vermells $i$ negres, $i$ que duien el títol de la seva empresa) juntament amb totes les sobrevestes, elms i espases, cimeres, retrees i ulleres respectives, al seu sotsarmer, Bernat Ferrer, que n'hi faria àpoca amb especificació de totes les coses lliurades, ACA, C., reg. 2413 , fol. 72 v. 1414 , maig, 18. Saragossa. 
entre les altres solempnitats de joya e de pler, havem ordonat que sie fet torneig de CC tornejadors de nobles e cavallers, entre los quals havem-vos elegit I de aquells, pregam e manam-vos que no falliscats per res de ésser a la solempnitat en la dita jornada. E venits ab vostre quart de companyons ben a cavall armats a vostra persona e de aquells, car nós vos farem liurar les sobrevestes per a vós e a ells e paraments e testeres als cavalls ${ }^{256}$.

Sembla ser, tanmateix, que no tots els que hi havien de participar ho feren, puix que, segons García de Santa María, destos dozientos caballeros vinieron al dicho torneo ciento y cinqüenta poco o menos, por quanto los otros que abian de venir tuvieron negocio de mengua de caballos e otras razones $^{257}$.

Les festes de la coronació de Ferran d'Antequera es van allargar fins al dilluns 19 de febrer, dia en què

el príncipe e el duque, hijos del rey, por honrar la fiesta de la reina su madre, ordenaron una justa muy estraña e fizieron poner en el Campo del Toro, do fue el gran torneo, quinze telas para justar, una llegada cerca de otra diez passos arredradas una de otra, e la una era valdía e la otra do abía de justar, e en la baldía miraban los cavalleros en manera que por las ocho justaban, e todos venían a ferir en el adarve a do estaban mirando el rey e la reina.

En efecte, com deien els documents, tant el príncep de Girona com el duc de Peñafiel, que hi tenien taula, hi prengueren part:

estando justando en estas telas, vinieron sin sospecha los fijos del rey, el príncipe e el duque, armados de torneo, e con ellos otros siete o ocho, e entraron en el adarve e las telas deyuso do el rey miraba e començaron su torneo a a dar unos en otros. E, como quiera que ambos andaban bien, pero el infante don Juan andaba muy desenvuelto según su edad.

E ansí obieron su solaz por acabamiento desta fiesta ${ }^{258}$.

\footnotetext{
${ }^{256}$ ACA, C., reg. 2383 , fol. 187 v. 1413, desembre, 13. Lleida; carta a Pere de Centelles, tramesa per igual a Jaume de Centelles cum quatuor equis paratis armatis i a Guillem de Muntanyans cum uno equo.

${ }^{257}$ D. FERRO, Le parti inedite, pp. 127-128.

${ }^{258}$ Ibidem, pp. 129-130.
} 


\begin{abstract}
RÉSUMÉ
Le couronnement de Ferran d'Antequera a suscité à plusieurs reprises l'intérêt des chercheurs, mais presque sans exception en prenant comme point de départ les chroniques et les sources narratives. Parmi les sources conservées aux Archives de la Couronne d'Aragon se trouve une grande quantité de documents relatifs aux préparatifs et à l'organisation de la fête permettant une parfaite confrontation et mise en relation des deux types de sources, avec une précision parfois surprenante. Cet article, donc, apporte un contrepoint documentaire aux informations déjà connues fournies par les chroniques sur le couronnement de Ferran Ir ${ }^{\text {tr }}$, un spectacle qui a suivi le rituel institué par les monarques antérieurs mais dans lequel se détâchait une forte composante légitimatrice, tant à cause des particularités de sa manière d'acceder au trône que par les contingences politiques internes immédiates, essentiellement le soulèvement de Jaume d'Urgell.
\end{abstract}

\title{
SUMMARY
}

Scholars have many times been attracted by Ferran d'Antequera's coronation but widely from chronistical and narrative sources though Corona d'Aragó Archives offer very rich documentation involving its preparations and organization. The celebration was an spectacle thoroughly faithful in pursuiving catalano-aragonese ritual, but designed in order to legitimize Ferran's unusual accession to the throne of Aragon. Archivistical sources allow to contrast and connect both kinds of information, often quite precisely. This work is meant a s a documentary contribution to know chronistical data of Ferran I coronation. 